\title{
Article
}

\section{Progress and Challenges in the Diagnosis of Dementia: A Critical Review}

\author{
Paraskevaidi, Maria, Martin-Hirsch, Pierre L. and Martin, Francis L \\ Available at https://clok.uclan.ac.uk/21618/ \\ Paraskevaidi, Maria, Martin-Hirsch, Pierre L. and Martin, Francis L orcid \\ iconORCID: 0000-0001-8562-4944 (2018) Progress and Challenges in the \\ Diagnosis of Dementia: A Critical Review. ACS Chemical Neuroscience, 8 (9). \\ pp. 446-461. ISSN 1948-7193
}

It is advisable to refer to the publisher's version if you intend to cite from the work. http://dx.doi.org/10.1021/acschemneuro.8b00007

For more information about UCLan's research in this area go to http://www.uclan.ac.uk/researchgroups/ and search for <name of research Group>.

For information about Research generally at UCLan please go to http://www.uclan.ac.uk/research/

All outputs in CLoK are protected by Intellectual Property Rights law, including Copyright law. Copyright, IPR and Moral Rights for the works on this site are retained by the individual authors and/or other copyright owners. Terms and conditions for use of this material are defined in the policies page.

\section{CLoK}

Central Lancashire online Knowledge www.clok.uclan.ac.uk

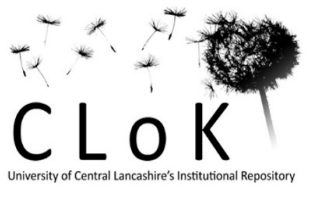


3

4

5 6

7

8

9

10

11

12

13

14

15

16

17

18

19

20

21

22

23

24

25

26

27

28 30

.

29 "To whom correspondence should be addressed. Email: mparaskevaidi@uclan.ac.uk or

\section{Progress and challenges in the diagnosis of dementia: a critical review}

(1)

Maria Paraskevaidia, ${ }^{\mathrm{a},}$, Pierre L. Martin-Hirsch $^{\mathrm{b}}$, Francis L. Martin $^{\mathrm{a}, *}$

${ }^{a}$ School of Pharmacy and Biomedical Sciences, University of Central Lancashire, Preston PRI 2HE, UK

${ }^{b}$ Department of Obstetrics and Gynaecology, Central Lancashire Teaching Hospitals NHS Foundation Trust, Preston PR2 9HT, UK

(1)
flmartin@uclan.ac.uk 


\section{ABSTRACT}

32 Longer life expectancies have led to an increased number of neurodegenerative disease cases globally. Accurate diagnosis of this devastating disorder is of crucial importance but is still feasible only by a brain biopsy after death. An enormous amount of attention and research has been in place over the years towards the better understanding of the mechanisms, as well as the early diagnosis, of neurodegeneration. However, numerous studies have been contradictory from time to time, while new diagnostic methods are constantly developed in a tireless effort to tackle the disease. Nonetheless, there is not yet a conclusive report covering a broader range of techniques for the diagnosis of different types of dementia. In this article, we critically review current knowledge on the different hypotheses about the pathogenesis of distinct types of dementia, as well as risk factors and current diagnostic approaches in a clinical setting, including neuroimaging, cerebrospinal (CSF) and blood tests. Encouraging research results for the diagnosis and investigation of neurodegenerative disorders are also reported. Particular attention is given to the field of spectroscopy as an emerging tool to detect dementias, followup patients and potentially monitor the patients' response to a therapeutic approach. Spectroscopic techniques, such as infrared and Raman spectroscopy, have facilitated numerous disease-related studies, including neurodegenerative disorders, and are currently undergoing trials for clinical implementation. This review constitutes a comprehensive report with an indepth focus on promising imaging, molecular biomarker and spectroscopic tests in the field of dementive diseases.

Keywords: neurodegenerative disease; dementia; biomarkers; diagnostic methods; neuroimaging; spectroscopy 


\section{INTRODUCTION}

Estimates of dementia prevalence have shown that 46.8 million people live with this condition worldwide and this is expected to reach 75 million by $2030^{1}$. People living with dementia are under-detected in high income countries, with only $20-50 \%$ of cases being accurately diagnosed in primary care; lack of diagnosis is even more evident in low- and middle-income countries ${ }^{2-4}$ (Fig. 1). The number of new cases of dementia every year was estimated to be over 9.9 million, implying one new case every 3.2 seconds ${ }^{5}$. A definitive diagnosis is still only been given post-mortem, thus an accurate detection is essential for providing an early intervention and improving the lives of those affected.

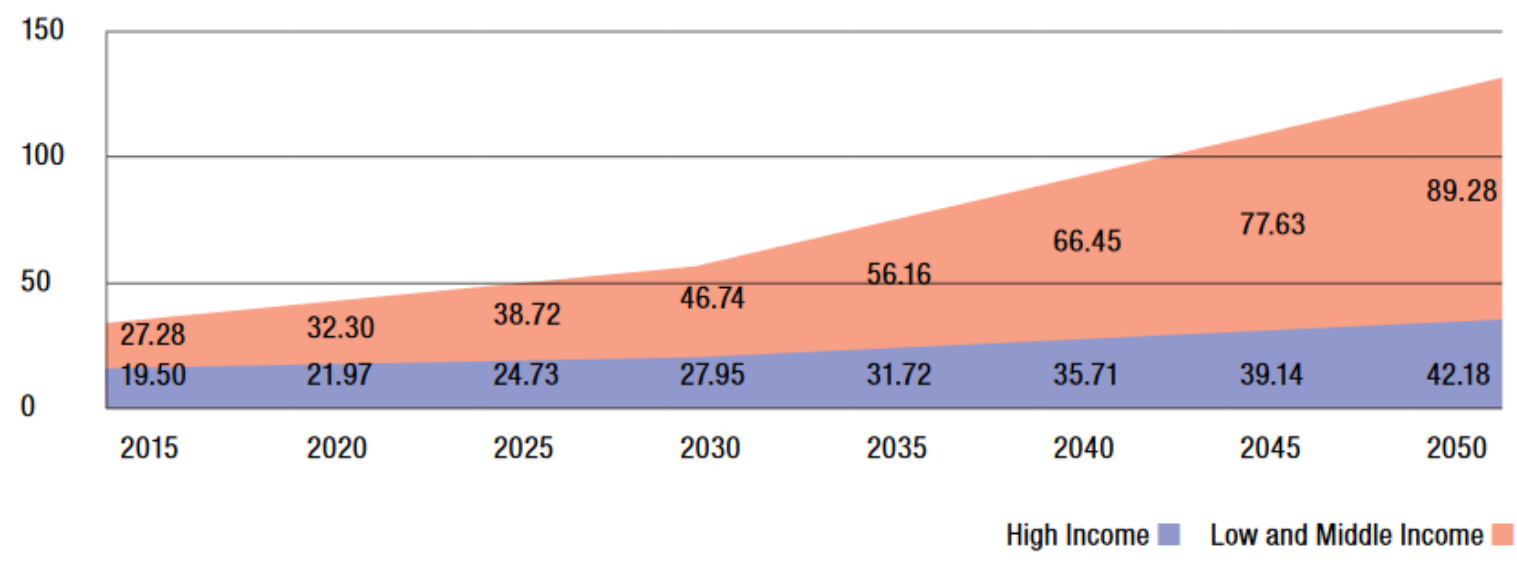

Figure 1: Estimation of people with dementia, in millions, in high- and low/middle-income countries. Adapted from ${ }^{5}$.

Symptoms of different dementias vary depending on the type but they all share some common characteristics, such as loss of memory and other mental abilities. Under the "umbrella" term of dementia, Alzheimer's disease (AD) and dementia with Lewy bodies (DLB) constitute the two most common types of underlying pathology ${ }^{6}$. Other, common types of dementia include vascular dementia (VaD), frontotemporal dementia (FTD), Parkinson's disease dementia (PDD) and mixed dementia ${ }^{7-9}$. The majority of the above-mentioned dementias undergo the same pathological mechanism of protein misfolding, which subsequently leads to clumps of proteins and neuronal death, with $\mathrm{VaD}$ being an exception as 
77 it has a distinct mechanism than the other dementias. Brain damage in VaD patients occurs due

to the lack of blood supply from bleeding, clotting or narrowing of arteries which can cause nerve cell injury or death. As AD often co-exists with $\mathrm{VaD}$, signs of both syndromes are most likely to be present. Furthermore, recent work by Novarino et al. has interestingly shown that, even though it does not fall into the spectrum of dementia, motor neuron disease (MND) has common features with other neurodegenerative disorders such as AD, PD and amyotrophic lateral sclerosis (ALS) ${ }^{10}$. This indicates that study of one neurodegenerative disease could possibly advance the understanding of others as well.

A number of risk factors have been associated with the development of neurodegenerative diseases and dementia. Increasing age, family history and susceptibility genes are some of the well-known unavoidable risk factors ${ }^{11-13}$. Numerous studies have associated neurodegeneration with a range of other risks which could be more easily managed, such as lifestyle choices (e.g., diet, exercise and alcohol intake) ${ }^{14-16}$, environmental factors (e.g., pesticides and neurotoxic metals, such as lead, mercury, arsenic) ${ }^{14,17}$, education ${ }^{18}$, gender ${ }^{19,20}$, Down syndrome ${ }^{21,22}$, head injuries ${ }^{23,24}$ or diabetes and cardiovascular diseases 25, 26. Recent findings have suggested that some factors could actually reduce risk in PD patients, including smoking, caffeine, and urate ${ }^{27}$. These could potentially act as neuroprotective agents and thus be beneficial for patients with early neurodegeneration. A use of these methods in clinical trials, facilitated by an accurate diagnosis with the techniques described in this paper, might be more effective at an early stage prior to significant brain damage. Current ongoing trials assessing long-term treatment with nicotine (using transdermal patches for over 60 months in early PD patients), caffeine (400 mg per day for five years) and inosine for urate elevation (using early PD patients to increase serum urate concentration within 24 months) aim to conclude whether these factors could facilitate therapeutic intervention or secondary prevention. 

complex interactions between any or all the above risk factors; this renders them complicated and difficult to study. The complexity of dementia is further demonstrated by the fact that drugs aiming to improve cognitive functions and delay the deterioration, such as cholinesterase inhibitors, still remain ineffective ${ }^{28,29}$. Much effort has been put on clinical trials, over the years, to help treat people experiencing dementia but without much success ${ }^{30,}{ }^{31}$. It is increasingly thought that drugs should be administered at an early, pre-symptomatic stage of dementia in order to provide successful treatment. However, there is yet no robust way to preclinically detect people who will develop dementia, which renders the need of early biomarkers crucial.

Research in the field of neurodegeneration and dementias currently undergoes fast progress. Promising results from recent studies have led to a wide consensus that dementia is a slowly progressive disease which means that a diagnosis may be feasible years before symptoms develop. An early diagnosis with biological markers would greatly facilitate and accelerate the development of effective drugs and/or allow the diagnosed individuals to make better lifestyle choices. However, different research groups have employed different diagnostic approaches and studied a range of diagnostic and/or prognostic biomarkers, thus causing controversy and debate regarding the optimal method to take forward. This review will present and evaluate current knowledge with regard to a number of different dementias, including both 'traditional' and novel diagnostic approaches.

\section{EPIDEMIOLOGY}

The types of dementia that will be studied in more detail in this critical review include

AD, DLB, FTD, VaD, PDD and mixed dementia. 
$\mathrm{AD}$ is the most common cause of dementia accounting for $60-80 \%$ of the cases.

127 Previous estimates have shown that $\sim 34$ million people worldwide have AD, with the prevalence expected to triple by $2050^{32}$. Determining the age of onset and defining a diseasefree cohort have been two of the reasons that incidence rates for AD are difficult to calculate.

130 After bringing together data from 24 published studies, Mayeux and Stern reported an approximate incidence of $0.5 \%$ per year for the age cohort $65-70$ years which increased to 6$8 \%$ for the individuals over 85 years of age (Fig. 2) ${ }^{33}$.

\section{Annual incidence rate (per 100 person-years)}

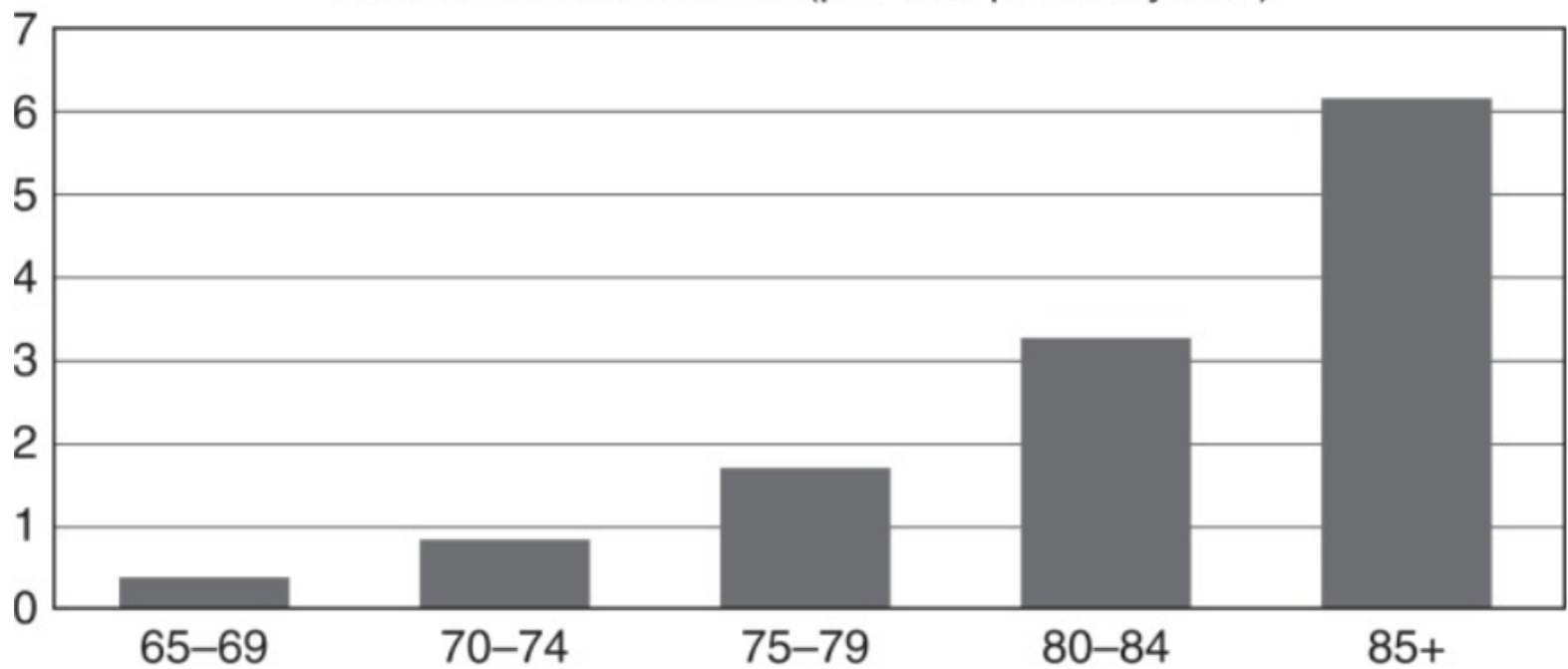

Figure 2: Annual incidence rate (per 100 person-years) for Alzheimer's disease. The graph illustrates an estimate of data from 24 published studies. Adapted from ${ }^{33}$. With permission from Cold Spring Harbor Laboratory Press.

The terminology of AD has been revised in the 2011 guidelines (after almost 30 years from the original criteria) to also include cases from the time point of the initial pathologic changes in the brain; in other words, before symptoms of memory loss incur ${ }^{34}$. Three different stages were suggested to characterise the disease according to its progression: preclinical (or pre-symptomatic) $\mathrm{AD}$; mild cognitive impairment $(\mathrm{MCI})$ due to $\mathrm{AD}$; and dementia due to $\mathrm{AD}$ (Fig. 3). In a preclinical stage, the key biological changes are under way but without presenting any obvious, clinical symptoms; this primary phase is thought to begin years in advance. MCI 
includes some changes in memory and thinking that can be noticeable but do not affect the ability for daily tasks; more importantly, not all people with MCI develop AD dementia eventually. In a meta-analysis of 41 cohort studies, it was found that only $38 \%$ of MCI

147 progressed to dementia during a follow-up period of 5 years ${ }^{35}$. Finally, the last stage of AD 148 due to dementia includes the well-known symptoms of memory loss as well as cognitive and behavioural impairment.

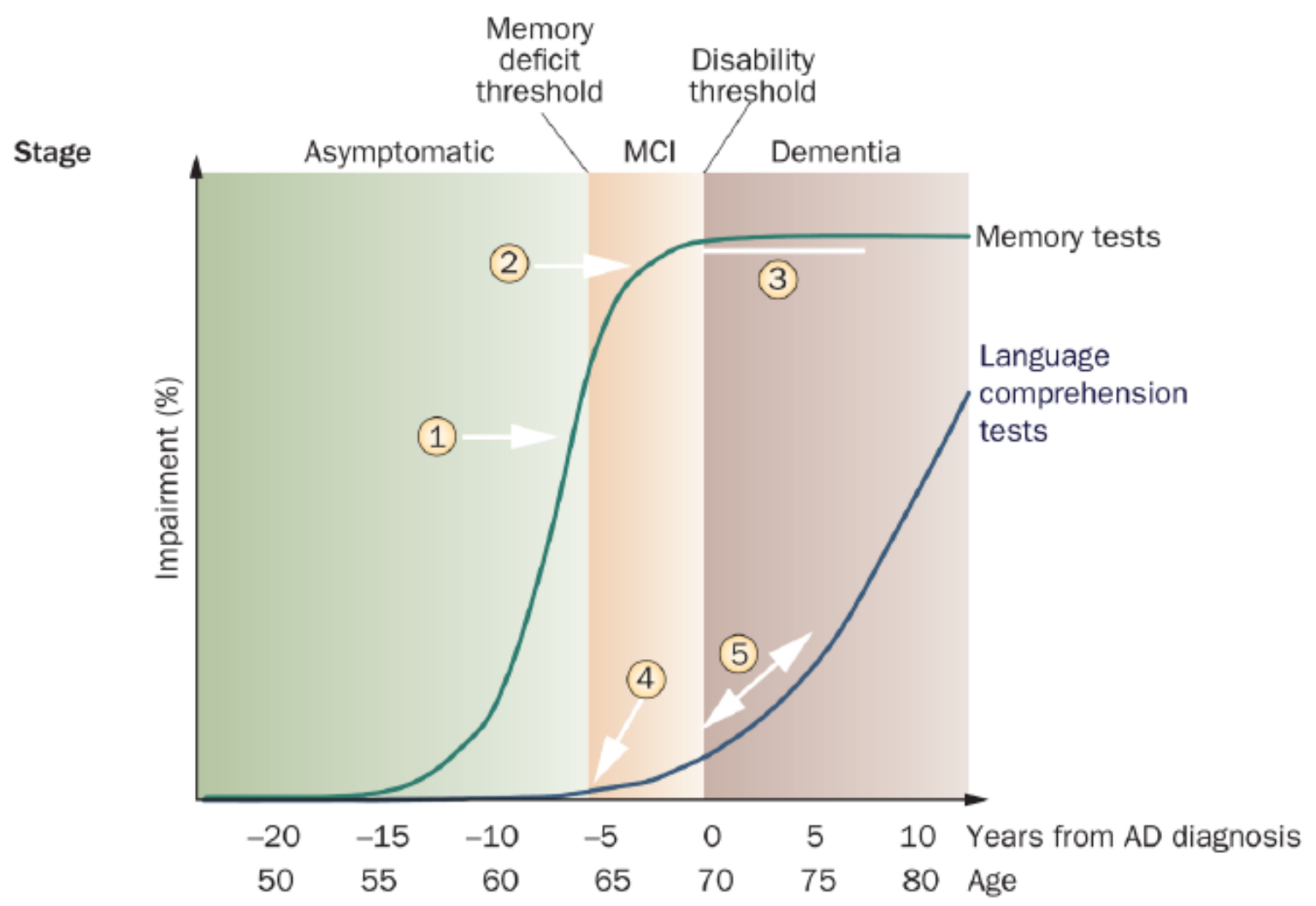

Figure 3: Known natural history of cognitive markers implies that memory tests, which change relatively early in the disease course (1) and soon reach the maximal level of impairment (2), are useful for diagnosis at the MCI stage, but are less useful for tracking later disease progression (3). Verbal comprehension tests start to change later in the disease course: during MCI they show mild or no impairment (4), and are of limited use in diagnosis. These markers become more sensitive at the dementia stage, when the slope of change steepens (5). Adapted from ${ }^{36}$. Reprinted by permission from: Springer Nature, Nature Reviews Neurology, The clinical use of structural MRI in Alzheimer disease, Giovanni B. Frisoni, Nick C. Fox, Clifford R. Jack Jr, Philip Scheltens, Paul M. Thompson (2010). License Number 4279300909074. 

role in developing the disease. AD can be either familial, which is inherited by a family member and is rarer, or sporadic. Family history and carrying the gene for the production of the apolipoprotein $\varepsilon 4$ (ApoE $\varepsilon 4)$ are now well-established risk factors. ApoE is a major cholesterol carrier and has three distinct isoforms: $\varepsilon 2, \varepsilon 3$ and $\varepsilon 4{ }^{37}$. The human ApoE protein contains 299 amino acids and despite the fact that the three isoforms differ by only one or two amino acids, their structure and function is entirely different ${ }^{38}$. Individuals with two alleles of $\varepsilon 4$ have $12-$ fold risk to develop the disease about 10-20 years earlier than others with no $\varepsilon 4$ alleles, whereas one $\varepsilon 3$ allele increases the risk 3 -fold. In contrast, $\varepsilon 2$ allele decreases the risk ${ }^{37,38}$. Previous studies have reported the frequency of $\mathrm{AD}$ and mean age at clinical onset being $91 \%$ and 68 years of age in $\varepsilon 4$ homozygotes; $47 \%$ and 76 years in $\varepsilon 4$ heterozygotes; and $20 \%$ and 84 years in $\varepsilon 4$ non-carriers (Fig. 4) ${ }^{37}$. Strong evidence suggests that the major mechanism by which ApoE influences $\mathrm{AD}$ is via its effects on $\mathrm{A} \beta$ metabolism ${ }^{38}$. The toxic events of ApoE are thought to initiate when the lipoproteins bind to several cell-surface receptors to deliver lipids and to amyloid- $\beta(\mathrm{A} \beta)$ peptide; this in turn leads to synaptic dysfunction ${ }^{37}$. Normally each ApoE isoform enhances the degradation of $A \beta$ but $A p o E \varepsilon 4$ seems to be less effective in $A \beta$ clearance ${ }^{37}$. Several mechanisms have been proposed for the role of ApoE in AD, such as promoting aggregation of $A \beta$ or phosphorylation of tau (Fig. 5).

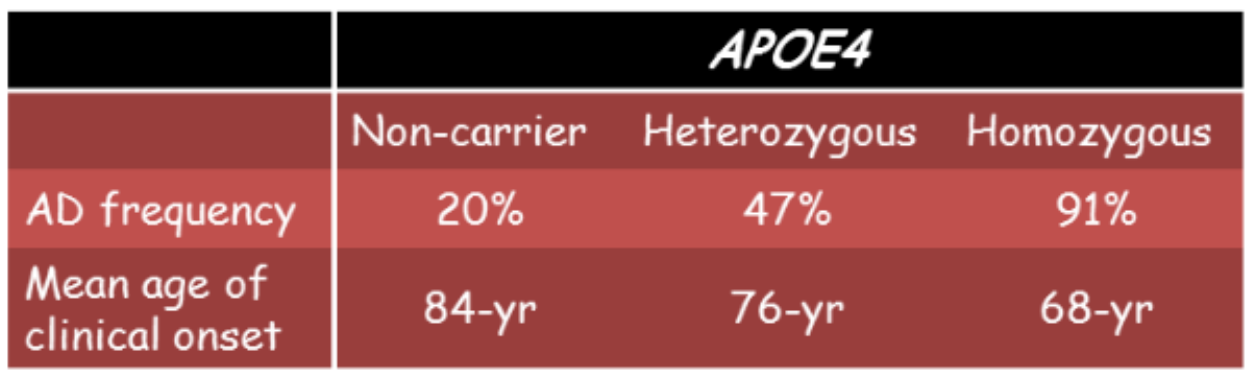

179 Figure 4: Apolipoprotein $\varepsilon 4(A P O E \varepsilon 4)$ as a genetic risk factor for AD. Adapted from ${ }^{37}$. 180 
and Alzheimer disease: risk, mechanisms and therapy, Chia-Chen Liu, Takahisa Kanekiyo, Huaxi Xu, Guojun Bu (2013). License Number 4279310010694.

\section{ApoE Isoforms, Levels, and Lipidation}

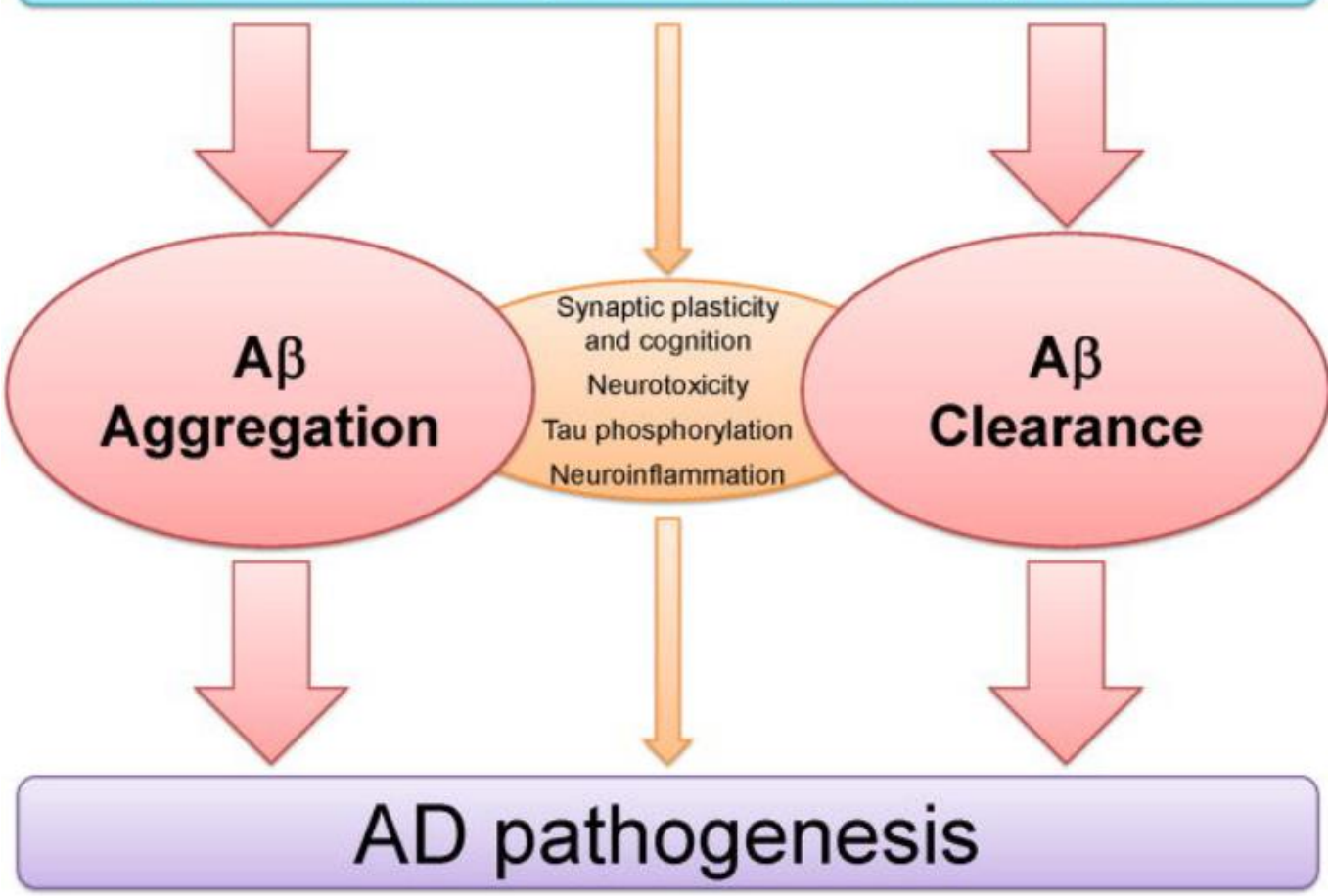

Figure 5: Proposed mechanisms for the role of apolipoprotein (ApoE) in AD pathogenesis. The major effect of ApoE isoforms on $\mathrm{AD}$ development is via its effect on $\mathrm{A} \beta$ aggregation and clearance. Other mechanisms, including the effects of ApoE isoforms on synaptic function, neurotoxicity, tau phosphorylation, and neuroinflammation, may also contribute. Independent of $A p o E$ genotype, differences in the ApoE levels and lipidation state may also mediate processes involved in AD pathogenesis. Adapted from ${ }^{38}$ (doi: 10.1038/nrneurol.2012.263). No changes have been made to the figure; License Number 4278980016081.

Other genetic factors that increase the risk of early-onset $\mathrm{AD}$ (i.e., below 65 years of age) include mutations in Amyloid Precursor Protein (APP), Presenilin 1 (PSEN1) and Presenilin 2 (PSEN2). APP is cleaved into fragments by $\alpha-, \beta$ - and $\gamma$-secretases; proteolysis by $\alpha$ - and $\gamma$-secretases results in non-pathogenic fragments whereas proteolysis by $\beta$ - and $\gamma$ secretases produces a mixture of $A \beta$ peptides: $A \beta_{1-40}(90 \%)$ and $A \beta_{1-42}(10 \%)$. $A \beta_{1-42}$ peptides 
are more likely to aggregate and form amyloid plaques in AD patients ${ }^{39}$. PSEN1 and PSEN2 proteins are essential components of the $\gamma$-secretase; thus, mutations of PSEN1 and PSEN2 result in an increased ratio $A \beta_{1-42} / A \beta_{1-40}$, either through an increased $A \beta_{1-42}$ production or decreased $A \beta_{1-40}$ production, or a combination of both. However, other studies have demonstrated contradictory results showing decreased or unchanged levels of the proteins 40 , 41. Another study has suggested that even though they found no differences in the CSF A $\beta_{1-42}$ or $A \beta_{1-40}$ production rate, there was an impairment of the clearance rate which subsequently led to higher levels of the protein ${ }^{42}$.

Over the years, different mechanisms have been proposed for the pathogenesis of AD and many more are suggested as our knowledge of the disease continues to evolve ${ }^{43,44}$. The two main hypotheses that have prevailed though include the amyloid cascade hypothesis which leads to the aggregation of toxic $A \beta$ oligomers, subsequently creating the extracellular $A \beta$ plaques in the brain, and the tau hypothesis which involves hyperphosphorylation of protein tau causing aggregation and deposits in the brain as intracellular neurofibrillary tangles (NFTs) 45. In a healthy brain, tau protein binds to microtubules to stabilise them with neuron cells and facilitate effective transport within the cell ${ }^{46}$; in $\mathrm{AD}$, however, tau protein becomes hyperphosphorylated which causes its detachment from the microtubules and subsequently the formation of oligomers and tangles. The theory of tau hyperphosphorylation is not universally accepted with some suggesting that post-translational modifications, other than phosphorylation, could promote the aggregation of tau; acetylation of tau, for instance, has been previously proposed to play a significant role in this ${ }^{47}$. The initial sites and spread of neurofibrillary tangles within the brain are entirely predictable; they start in the allocortex of the medial temporal lobe (entorhinal cortex and hippocampus), then spread to the associative isocortex, sparing the primary sensory, motor and visual areas until the very end stages ${ }^{48,49}$. Similarly, $A \beta$ deposition is also predictable ${ }^{50}$, starting in the isocortical areas of the brain, then 
spreading to allocortical brain regions and in the later stages to subcortical structures, including the basal ganglia and the cerebellar cortex ${ }^{48}$.

\section{Dementia with Lewy bodies (DLB)}

DLB is the second most common type of dementia after AD, sharing clinical and pathological characteristics with both AD and PD. The incidence of DLB had been estimated $\sim 0.1 \%$ a year for the general population and accounts for $3.8 \%$ of new dementia cases ${ }^{51,52}$. The pathological hallmark of this type of dementia is the formation of characteristic clumps of proteins, called Lewy bodies (LBs). The main structural component of LBs is $\alpha$-synuclein which is also found in patients with PD and multiple system atrophy (MSA), all of which are defined as synucleinopathies ${ }^{53}$. However, LBs have also been associated with neurofibrillary tangles and $\mathrm{A} \beta$ plaques which are mostly present in $\mathrm{AD}$. Alpha-synuclein consists of 140 amino acids and is encoded by the $S N C A$ gene ${ }^{54}$. Nevertheless, due to the constant and abundant A $\beta 42$ in DLB cases, it has been suggested that synucleinopathy is also promoted by $A P P$ dysfunction 55 .

DLB and AD have many symptoms in common leading to frequent misdiagnosis.

Differential diagnosis of the two subtypes of dementia is crucial to provide a more accurate prognosis, administration of the appropriate treatment and/or inclusion to a suitable clinical trial. For instance, even though DLB cases respond well to drugs prescribed to AD patients, such as cholinesterase inhibitors, they also have severe neuroleptic sensitivity reactions, which are associated with significantly increased morbidity and mortality ${ }^{56}$. Previous work studying the survival and mortality differences between AD and DLB showed that DLB patients had increased risk of mortality with a median survival time of 78 years, which in AD was 84.6 years 57 . 
In an effort to improve the management of this disorder, new international guidelines were very recently established ${ }^{6}$. Clinically, DLB presents with symptoms of dementia and delirium-like alterations in cognition, attention and arousal. Other clinical symptoms, less frequent in $\mathrm{AD}$, include visual hallucinations, rapid eye movement (REM) sleep behaviour disorder and Parkinsonism. Other, supportive symptoms indicating the disease are hypersomnia, presenting as excessive daytime sleepiness and hyposmia, which occurs earlier in DLB than AD cases. Imaging, genetic and fluid biomarkers have also been established for the diagnosis of DLB ${ }^{6}$. It has also been suggested that accumulation of LB pathology starts in the brainstem, then spreads progressively to limbic regions and finally cerebral neocortex ${ }^{58}$.

Frontotemporal dementia (FTD)

Frontotemporal lobar degeneration (FTLD) is a broader term to describe three syndromes that affect the frontal and temporal lobes of the brain: frontotemporal dementia (FTD) mainly causing behavioural changes, semantic dementia (SD) mainly causing impaired word comprehension and semantic memory, and progressive non-fluent aphasia (PNFA) mainly causing impaired speech production ${ }^{59,60}$. Of those, FTD, or else Pick's disease, is the most common clinical phenotype; it is thought to be third after AD and DLB, with a prevalence ranging from $3 \%$ to $26 \%$ in people with early onset dementia (i.e., <65 years of age) ${ }^{61}$. This subtype is particular common in younger patients (i.e., <45 years: $10 \%$ prevalence; 45-64 years: $60 \%$ prevalence; $>64$ years: $30 \%$ prevalence). As the disease progresses with duration, patients develop global cognitive impairment and motor deficits which inevitably lead to death.

Death usually occurs after eight years after symptom onset and is frequently due to pneumonia or secondary infections ${ }^{61}$.

Some of the clinical symptoms of FTD include progressive deterioration of behaviour and/or cognition as well as behavioural disinhibition (e.g., socially inappropriate behaviour or 
loss of manners), apathy or inertia, loss of sympathy and empathy (e.g., diminished response to others' needs and feelings), stereotyped or compulsive/ritualistic behaviour (e.g., repetitive movements) or hyperorality and dietary changes (e.g., consumption of inedible objects, altered food preferences) ${ }^{62}$. Due to the similarity of behavioural changes with those seen in psychiatric disorders, such as compulsive behaviours, delusions and euphoria, diagnosing FTD can be challenging ${ }^{61}$. Also, overlap of symptoms with other neurodegenerative disorders such as AD, DLB, corticobasal syndrome (CBS) and progressive supranuclear palsy (PSP), renders the differential diagnosis even more difficult ${ }^{60}$.

\section{Vascular dementia (VaD)}

$\mathrm{VaD}$, also known as a single- or multi-infarct dementia, causes around $10 \%$ of dementia cases and develops in around $15-30 \%$ of individuals three months after a stroke. ${ }^{63}$. Risk factors for $\mathrm{VaD}$ can be divided into four categories: demographic (e.g., age, gender, educational level), genetic (e.g., ApoE4, familial vascular encephalopathies), atherosclerotic (e.g., hypertension, smoking, myocardial infarction, diabetes mellitus) and stroke-related (e.g., volume of cerebral tissue lost, bilateral cerebral infarction, white matter disease) ${ }^{64}$. Having one or two ApoE4 alleles has been found to elevate the risk but not to the same extent as in $\mathrm{AD}^{65}$.

$\mathrm{VaD}$ patients can present with different extents of impaired memory and, in contrast to $\mathrm{AD}$, this criterion of memory disturbance cannot provide an accurate diagnosis. Cognitive changes also vary significantly, and thus it is thought that the classical mini-mental state examination (MMSE) may be less efficient for $\mathrm{VaD}$. Another difference from $\mathrm{AD}$ is that the brain pathology is not developing in a predictable pattern and there is still no agreed pathological scheme to facilitate diagnosis and staging. Trials that have utilised drugs originally destined for $\mathrm{AD}$ have shown that these may not be appropriate for $\mathrm{VaD}$ as well ${ }^{63}$. The rationale for trial of cholinesterase inhibitors and memantine (both established for AD) in VaD patients 
was based on evidence of their common features and specifically the cholinergic deficit seen in $\mathrm{VaD}$. However, it was later suggested that the cholinergic system might not be affected in $\mathrm{VaD}$ alone, but be affected to the same extent as in $\mathrm{AD}$ in cases of mixed dementia (i.e., $\mathrm{VaD}$ and $\mathrm{AD}$ ). Even though there has been substantial progress, $\mathrm{VaD}$ is yet under-investigated and further research is necessary to elucidate the pathologic mechanisms and facilitate treatment strategies.

\section{Parkinson's disease dementia (PDD)}

As patients with Parkinson's disease (PD) progress with time, they often develop a progressive dementia which is similar to AD and DLB. For PDD, a preceding diagnosis of PD, before any symptoms of dementia, is necessary; in contrast, when both parkinsonism and dementia arise in early stages, then DLB is the most likely cause of degeneration ${ }^{66}$. The prevalence of PDD has been estimated to almost $0.2-0.5 \%$ in individuals older than 65 years 67, while the incidence rate was found 2.5 per 100,000 person/year for all ages (0-99 years), which increased to 23 per 100,000 person/year for older individuals (>65 years) ${ }^{68}$.

The major pathological feature of PDD is the aggregation of $\alpha$-synuclein mainly in the substantia nigra of the brain; these clumps impair dopaminerging nerve cells thus leading to the characteristic motor and non-motor symptoms of PD ${ }^{69,70}$. Previous work on the clinical symptoms of PDD has shown that decline in attention, executive functions and visuo-spatial construction is greater than in $\mathrm{AD}$, whereas verbal and visual memory as well as language function are less impaired than in $\mathrm{AD}^{71}$. Also, delusions have been reported to be less common than $\mathrm{AD}$ and $\mathrm{DLB}$, prevalence of depression is thought to be higher than $\mathrm{AD}$, anger and aggressive behaviour was found more common in AD and sleep quality in PDD and DLB was poorer than $\mathrm{AD}$ and normal controls ${ }^{71}$.

\section{Mixed dementia}



thought, with pathology resulting from more than one causes. Brain changes result from the combination of pathological hallmarks of different dementive diseases such as AD, DLB and $\mathrm{VaD}^{72,73}$.

The coexistence of $\mathrm{AD}$ and $\mathrm{VaD}$ is a very common type of mixed dementia; according to an autopsy study, $45 \%$ AD patients also had cerebrovascular pathology ${ }^{74}$. A recent paper also indicated that in people over 80 years, mixed dementia is the norm, not the exception ${ }^{63}$. It has, thus, been proposed that assessing symptoms by investigating only one pathology may not apply to older patients who are at-risk from both $\mathrm{AD}$ and cerebrovascular disease ${ }^{9}$.

Similarly, the majority of DLB cases also have co-existing AD pathology ${ }^{57,75}$. A previous study has shown that combining different pathologies from AD and LBs (i.e., A $\beta$, tau and $\alpha-$ synuclein) was a better predictor of PDD than assessing any single pathology ${ }^{76}$.

\section{CORRELATION OF DEMENTIA \& HEAD INJURY} repeated head injuries, is one of the risk factors for the development of dementia. Chronic traumatic encephalopathy (CTE), previously known as dementia pugilistica, is caused by TBI. The abnormal accumulation of hyperphosphorylated tau protein, along with $\mathrm{A} \beta$ plaques, are the key components in the brains of CTE patients ${ }^{77}$ which are also common to other dementia subtypes, rendering an accurate diagnosis challenging. that an individual eventually goes on to develop CTE ${ }^{23}$. This could serve as a time window and allow for a preclinical, early-phase diagnosis which may subsequently lead to the 
include memory impairment, behavioural and personality changes, Parkinsonism, and abnormalities in speech and gait ${ }^{78}$.

Previous neuropathological studies have detected CTE in brains of athletes who played box, rugby, soccer, baseball and ice hockey, as well as in subjects who had experienced a brain trauma from physical abuse, head-banging or even an explosion in a military combat ${ }^{77}$. A very recent study on 202 deceased football players revealed that 177 of them (87\%) had CTE at biopsy, suggesting that it may be related with their prior participation in football ${ }^{24}$. However, at present, a definitive diagnosis for CTE is only given after neuropathological examination biomarkers such as CSF and blood biomarkers.

\section{CURRENT DETECTION METHODS}

A definitive diagnosis of dementia can only be given post-mortem after histopathological examination of the brain tissue. However, a working diagnosis can be provided clinically after and blood testing. Newly discovered biomarkers and techniques have been proposed to improve the diagnostic accuracy and characterization of dementive diseases (Table 1).

The Mini-Mental State Examination (MMSE) is the most widely used cognitive screening tool to provide an initial assessment of cognitive impairment, as well as to monitor the progression of the disease with time ${ }^{79}$. The MMSE is in the form of a 30-point questionnaire with a score less or equal to 24 denoting dementia; it assesses temporal and spatial orientation, memory as well as language and visuospatial functions. However, it requires the presence of symptoms and therefore it is not effective with preclinical, asymptomatic cases. Recent studies have shown that more tests, other than MMSE, should be used as its utility is decreased when 
individuals with MCI and psychiatric conditions are assessed ${ }^{80,81}$. Aside from MMSE, neurological assessment should be conducted in patients with possible cognitive impairment to evaluate ataxia, anosmia, involuntary movements, reflexes, visual acuity and other signs ${ }^{82}$. For instance, as $\mathrm{AD}$ progresses the patients may develop akinesia, rigidity and myoclonus due to the extended impairment of cortical and subcortical structures; patients with PDD will present with bradykinesia, akinetic-rigid symptoms, depression, early visual hallucinations due to subcortical dysfunctions in the areas of executive function and memory; the initial presentations of FTD patients include personality change, emotional problems and behavioural disturbance; in $\mathrm{VaD}$ some of the common clinical symptoms include dysarthria, dysphagia, rigidity, visuospatial deficits, ataxia and pyramidal or extrapyramidal signs; DLB often involves visual hallucinations, parkinsonism and fluctuating attention and alertness with intervals of clarity ${ }^{82}$. Predisposing family history is also important for a complete assessment. Even though having a first-degree relative with dementia increases the risk, it does not necessarily lead to dementia. Other environmental and lifestyle factors have been suggested to play a significant role as well ${ }^{83}$.

Brain imaging techniques, such as magnetic resonance imaging (MRI) and positron electron tomography (PET), are also widely used in the diagnosis and monitoring of dementias. Structural MRI can indicate the presence of neurodegeneration by showing the tissue damage and loss in characteristic regions of the brain such as the hippocampus and other temporal lobe structures ${ }^{36}$. PET imaging techniques can either use ${ }^{18}$ F-fluorodeoxyglucose $\left({ }^{18} \mathrm{~F}\right.$-FDG) to measure the glucose hypometabolism and neurodegeneration, or ${ }^{11} \mathrm{C}$ Pittsburgh compound $\mathrm{B}$ $\left({ }^{11} \mathrm{C}-\mathrm{PiB}\right)$ to visualise the $\mathrm{A} \beta$ plaques ${ }^{84,85}$. Tau PET has been developed to visualise the regional distribution of tau pathology in vivo using suitable tau-specific tracers. The ability to investigate the patterns of tau deposition holds great promise for the future as it would facilitate the segregation between different neurodegenerative diseases, including tauopathies. It has also 
been demonstrated that tau imaging, in contrast to $A \beta$ imaging, is strongly associated with patterns of neurodegeneration and clinical presentation of AD. It is, however, still in early stages of development and further research needs to be conducted to validate the sensitivity of tau PET for age-related tau accumulation ${ }^{86,87}$.

Biological fluids, such as cerebrospinal fluid (CSF) and blood, are increasingly utilised for the diagnosis, prognosis and monitoring of dementias ${ }^{88}$. Three of the main proteins that have been studied extensively are total tau (T-tau), phosphorylated tau (P-tau) and $\mathrm{A} \beta_{42}{ }^{36}$, but a number of other biomarkers have been recently reported to be moderately associated with AD as well, such as neurofilament light chain (NfL), vinisin-like protein 1 (VLP-1), neuronspecific enolase (NSE), heart fatty acid binding protein (HFABP) and glial activation (YKL40) ${ }^{88}$. T-tau and P-tau have been repeatedly found elevated in patients with AD and are indicative of neuronal degeneration and accumulation of tau, respectively ${ }^{85}$. P-tau is more specific for AD whereas T-tau can be increased in other brain disorders as well, such as stroke and brain trauma non-AD dementias ${ }^{89}$. As previously mentioned, results have been controversial among different research groups ${ }^{90}$; for instance, $\mathrm{A} \beta_{42}$ level in CSF has been reported to decrease ${ }^{85,88}$ or increase ${ }^{91}$, in comparison to healthy subjects, but was found unchanged in blood plasma samples ${ }^{88}$. Other studies have reported a reduction in plasma $A \beta_{42}$ in $\mathrm{MCI}$ and $\mathrm{AD}$ subjects ${ }^{92}$ while serum $\mathrm{A} \beta_{42}$ was found unchanged in $\mathrm{AD}$ and healthy normals 93. The inconsistent results may occur due to changes in age and timing relative to incident AD 94. A more detailed summary of these biomarkers is given in Table 1.

\section{BIOSPECTROSCOPY AS AN EMERGING DIAGNOSTIC MEANS}

Vibrational spectroscopy has been increasingly used in biomedical research to discriminate and classify normal and pathology. Interrogation of samples with spectroscopic techniques, and more specifically infrared (IR) and Raman spectroscopy, allows for the 
413 generation of a "spectral fingerprint" which subsequently facilitates the discrimination of 414 different populations and identification of potential biomarkers. As previously described, mixed dementias are now recognised as a highly common phenomenon; with this in mind, we

416 believe that targeting specific molecules and investigating separate pathological pathways may 417 not provide a complete picture. On the contrary, with spectroscopy it is feasible to 418 simultaneously study a range of different biomolecules. Unlike immunological methods, which 419 detect only one molecule at a time, the spectra obtained from a clinical sample represent a range of biomolecules such as proteins, lipids and carbohydrates (Figure 6). biological sample in question (e.g., tissue, CSF, blood) is shone with light of specific electromagnetic radiation which causes the samples' molecules to vibrate. These characteristic, generated movements are then detected and depicted in the form of a spectrum. Spectral peaks correspond to specific biomolecules and can be used as potential biomarkers for disease. Further spectral analysis can also allow classification of the diseased and healthy population and diagnostic values (i.e., sensitivity and specificity) can be determined.

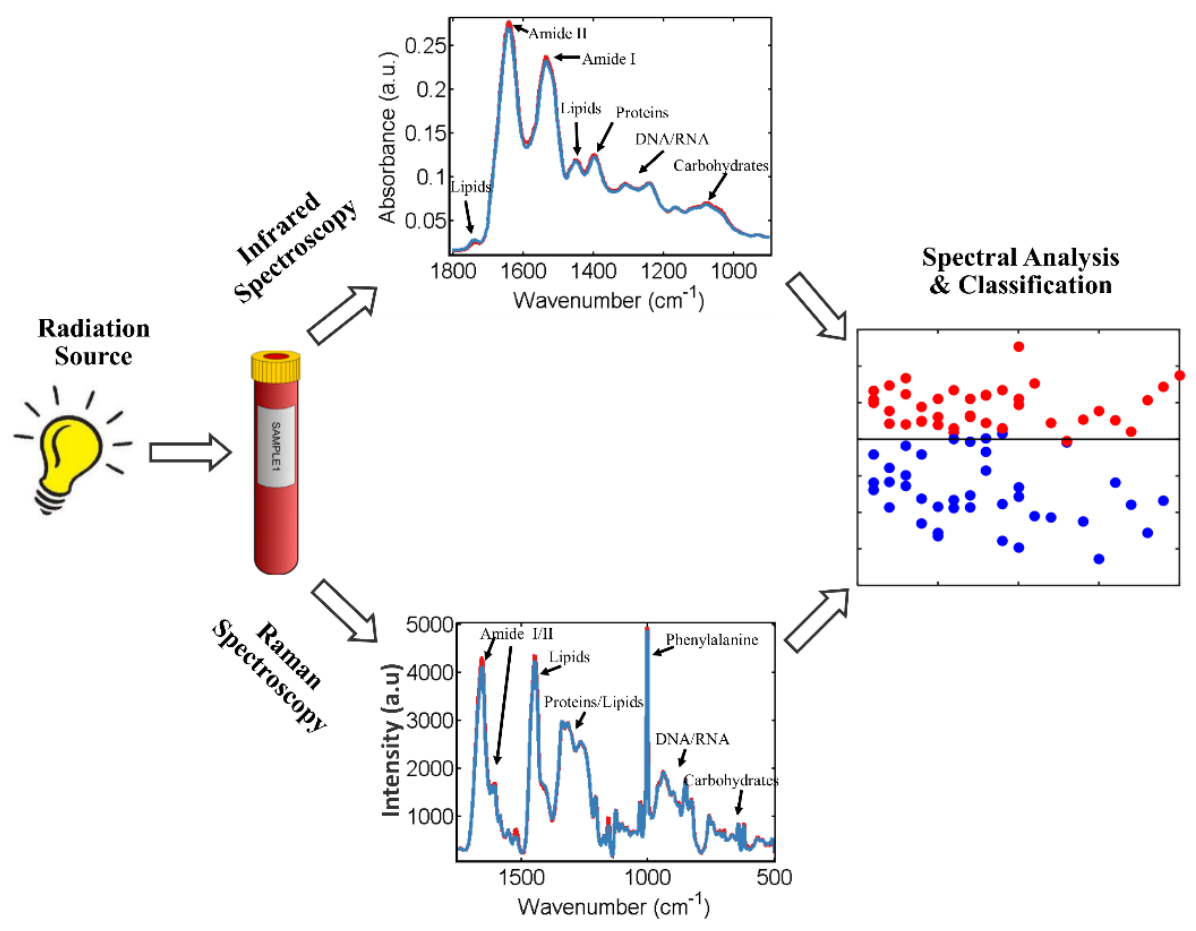


429 Figure 6: The basic principle of biospectroscopy: a source is used to direct radiation to the 430 clinical sample and cause vibrations to its molecules - spectral information is generated -

431 spectral analysis allows for classification and biomarker extraction.

At present, a number of spectroscopic studies have achieved promising results in diagnosing dementia subtypes and some examples will be presented in this section. Two decades ago, the first evidence of the structure of $A \beta$ plaques was revealed by IR microspectroscopy methods after in situ analysis of a section of AD brain ${ }^{95}$. This showed that the plaques in the brain consisted of $\beta$-sheet in contrast to the surrounding areas which gave signal of $\alpha$-helical and/or unordered conformation.

Low levels of unsaturated lipids have been suggested to increase the risk or severity of AD. Using IR imaging, Leskovjan et al., visualised the unsaturated lipid levels in the axonal, dendritic and somatic layers of the hippocampus of an $\mathrm{AD}$ mouse model as a function of plaque formation ${ }^{96}$. As the disease progressed, the lipid unsaturation in the axonal layer was found significantly lower when compared to normal aging subjects, suggesting that maintenance the level of unsaturated lipid content may be critical in slowing down the disease.

A following paper tested 50 AD cases against 14 healthy subjects with both IR and Raman spectroscopy to account for potential changes in peripheral blood ${ }^{97}$. An increased spectral peak found in AD patients, denoted $\beta$-sheet enrichment and was attributed to A $\beta$ peptide formation. Diagnostic approaches were used to distinguish the patients from the healthy individuals and achieved an accuracy of $\sim 94 \%$.

Another study analysed both CSF and blood plasma using an immune-IR-sensor to measure the $A \beta$ peptide secondary distribution ${ }^{98}$. The IR-sensor detected a significant downshift of the Amide I spectral region in patients with AD. The authors concluded that the shift signalled the transition from a healthy to a dementive status which was depicted in the 
spectra from a transition from $\alpha$-helical $\left(1652 \mathrm{~cm}^{-1}\right)$ to $\beta$-sheet $\left(1627 \mathrm{~cm}^{-1}\right)$ spectral region. The achieved diagnostic accuracy was $90 \%$ for CSF and $84 \%$ for blood samples.

Recently, Paraskevaidi et al. published the results of a large-cohort study showing IR spectroscopy's ability to discriminate different types of dementia in blood ${ }^{99}$. The study incorporated AD, DLB and FTD as well as other neurodegenerative disorders, such as PD, and achieved exceptionally high diagnostic accuracy. Distinctive patterns were seen between the dementia subtypes representing different pathological changes, mostly attributed to proteins and lipids. The high sensitivity and specificity achieved for distinguishing AD from DLB were outstanding (90\%) and would potentially provide an excellent diagnostic test. A small number of early-stage $\mathrm{AD}$ cases was also included and showed $80 \%$ sensitivity and $74 \%$ specificity. A following study by the same group employed Raman spectroscopy achieving equal, and in some cases even higher, diagnostic accuracies, thus establishing the effectiveness of biospectroscopy as a diagnostic tool ${ }^{100}$. An additional advantage of Raman spectroscopy over IR is its ability to analyse aqueous samples which would allow the analysis of fresh samples without the need of prior dehydration; this would be particularly beneficial for use in a clinic.

The inherently weak signal of spontaneous Raman spectroscopy can be addressed by employing signal enhancement techniques, such as surface enhanced Raman spectroscopy (SERS) or coherent anti-Stokes Raman scattering (CARS). A recent review by Devitt et al., has explored the promise of Raman spectroscopic techniques as an emerging tool to study and diagnose neurodegenerative disorders ${ }^{101}$. A number of diseases have been reviewed in this paper, namely $\mathrm{AD}, \mathrm{PD}$, prion diseases and Huntington's disease. The cost-effectiveness of spectroscopy over other expensive and laborious techniques has also been demonstrated, suggesting its potential for translation into clinic. More studies that have employed spectroscopy to study different types of dementias and their mechanisms are given in Table 1 . 


\section{CONCLUSIONS AND FUTURE PERSPECTIVE}

478

Improvement of health care and scientific breakthroughs have resulted in increased life expectancy. Data from the World Health Organization (WHO) have indicated that global average life expectancy increased by 5 years between 2000-2015, making it the fastest increase since 1960 s; this is estimated to increase by 4 more years by $2030^{102}$. Due to their common appearance at an older age, neurodegenerative diseases have become a major challenge for scientific and medical communities. It is now thought that future treatments aiming to delay or even stop/reverse the disease would be effective if administered at an early stage. Therefore, it is crucial to develop new techniques and biomarker tests that would allow the detection of presymptomatic individuals. An on-time diagnosis of patients who are destined to develop the disease would allow them to enroll in clinical trials with the hope that this would prevent the disease.

Another important consideration is that the affected persons and their families need to be adequately informed about the disease characteristics, symptoms, prognosis, available treatments and ongoing clinical trials so that they can plan their future, develop strategies and seek healthcare assistance if necessary.

A more reliable, affordable and less-invasive test is an unmet need in the field of neurodegeneration. Despite the significant advancement in deciphering the underlying pathology and mechanisms, these diseases remain incurable. Much effort has been put into alternative methodologies such as spectroscopic methods, which provide a panel of different biomolecules, rather than focusing on specific molecules, such as $\mathrm{A} \beta$ and tau proteins. Biospectroscopy can be a label-free, non-destructive and inexpensive method and it has shown potential as a means for diagnosing and/or monitoring disease progression. Surely, as with every novel method or biomarker, additional research is needed for the repetition and validation 
of current studies in larger cohorts and from different research groups. The new knowledge acquired could then be incorporated into the diagnostic criteria and guidelines. Minimally invasive sampling, such as in blood plasma and serum, are gaining increasing attention as biomarkers in neurodegenerative diseases. Changes in the blood are often subtle and may reflect a range of peripheral and central processes; however, with increasing age the bloodbrain barrier is disrupted and it has also been found that $500 \mathrm{ml}$ of CSF is daily discharged into the bloodstream which renders it an information-rich sample ${ }^{103,104 .}$

To summarise, there has been a great advancement in the understanding of the complex neurodegenerative processes. World-leading experts are now confident that we are approaching a major breakthrough in the field of dementia which could potentially improve patients' lives by alleviating or even curing the devastating symptoms of the condition. There is also a strong consensus that a definitive and early diagnosis would more likely be given after a combination of different biomarkers and analytical methods, rather than a focus on traditional approaches; perhaps an unconventional and "fresh" look on the problem is the key for a turning point in dementia research. Increasing research funding is also a very important factor that has to be secured in order to accelerate the pace of progress and continuous efforts should be made to maintain this.

\section{ACKNOWLEDGEMENTS}

MP acknowledges Rosemere Cancer Foundation for funding.

\section{AUTHOR CONTRIBUTIONS}

MP conducted the literature search and assessed the studies that were included in this review; MP wrote the manuscript; PLMH and FLM provided constructive feedback during manuscript preparation. All authors have contributed with critical revisions to manuscript. 


\section{REFERENCES}

[1] Prince, M. J. (2015) World Alzheimer Report 2015: the global impact of dementia: an analysis of prevalence, incidence, cost and trends, Alzheimer's Disease International.

[2] Nakamura, A. E., Opaleye, D., Tani, G., and Ferri, C. P. (2015) Dementia underdiagnosis in Brazil, Lancet 385, 418-419.

[3] Lang, L., Clifford, A., Wei, L., Zhang, D., Leung, D., Augustine, G., Danat, I. M., Zhou, W., Copeland, J. R., and Anstey, K. J. (2017) Prevalence and determinants of undetected dementia in the community: a systematic literature review and a meta-analysis, BMJ open 7, e011146.

[4] Ferri, C. P., and Jacob, K. (2017) Dementia in low-income and middle-income countries: Different realities mandate tailored solutions, PLoS Med 14, e1002271.

[5] International, A. s. D. (2015) World Alzheimer Reports, Alzheimer's Disease International.

[6] McKeith, I. G., Boeve, B. F., Dickson, D. W., Halliday, G., Taylor, J.-P., Weintraub, D., Aarsland, D., Galvin, J., Attems, J., Ballard, C. G., Bayston, A., Beach, T. G., Blanc, F., Bohnen, N., Bonanni, L., Bras, J., Brundin, P., Burn, D., Chen-Plotkin, A., Duda, J. E., El-Agnaf, O., Feldman, H., Ferman, T. J., ffytche, D., Fujishiro, H., Galasko, D., Goldman, J. G., Gomperts, S. N., GraffRadford, N. R., Honig, L. S., Iranzo, A., Kantarci, K., Kaufer, D., Kukull, W., Lee, V. M. Y., Leverenz, J. B., Lewis, S., Lippa, C., Lunde, A., Masellis, M., Masliah, E., McLean, P., Mollenhauer, B., Montine, T. J., Moreno, E., Mori, E., Murray, M., O'Brien, J. T., Orimo, S., Postuma, R. B., Ramaswamy, S., Ross, O. A., Salmon, D. P., Singleton, A., Taylor, A., Thomas, A., Tiraboschi, P., Toledo, J. B., Trojanowski, J. Q., Tsuang, D., Walker, Z., Yamada, M., and Kosaka, K. (2017) Diagnosis and management of dementia with Lewy bodies: Fourth consensus report of the DLB Consortium, Neurology 89, 88-100.

[7] Barker, W. W., Luis, C. A., Kashuba, A., Luis, M., Harwood, D. G., Loewenstein, D., Waters, C., Jimison, P., Shepherd, E., and Sevush, S. (2002) Relative frequencies of Alzheimer disease, Lewy body, vascular and frontotemporal dementia, and hippocampal sclerosis in the State of Florida Brain Bank, Alzheimer Disease Dis Assoc Disord 16, 203-212.

[8] Emre, M. (2003) Dementia associated with Parkinson's disease, Lancet Neurol 2, 229-237.

[9] Langa, K. M., Foster, N. L., and Larson, E. B. (2004) Mixed dementia: emerging concepts and therapeutic implications, JAMA 292, 2901-2908.

[10] Novarino, G., Fenstermaker, A. G., Zaki, M. S., Hofree, M., Silhavy, J. L., Heiberg, A. D., Abdellateef, M., Rosti, B., Scott, E., and Mansour, L. (2014) Exome sequencing links corticospinal motor neuron disease to common neurodegenerative disorders, Science 343, 506-511.

[11] Niccoli, T., and Partridge, L. (2012) Ageing as a Risk Factor for Disease, Curr Biol 22, R741-R752.

[12] Donix, M., Ercoli, L. M., Siddarth, P., Brown, J. A., Martin-Harris, L., Burggren, A. C., Miller, K. J., Small, G. W., and Bookheimer, S. Y. (2012) Influence of Alzheimer Disease Family History and Genetic Risk on Cognitive Performance in Healthy Middle-Aged and Older People, Am J Geriatr Psychiatry 20,10.1097/JGP.1090b1013e3182107e3182106a.

[13] Cuyvers, E., and Sleegers, K. (2016) Genetic variations underlying Alzheimer's disease: evidence from genome-wide association studies and beyond, Lancet Neurol 15, 857-868.

[14] Brown, R. C., Lockwood, A. H., and Sonawane, B. R. (2005) Neurodegenerative Diseases: An Overview of Environmental Risk Factors, Environ Health Perspect 113, 1250-1256.

[15] Joseph, J., Cole, G., Head, E., and Ingram, D. (2009) Nutrition, brain aging, and neurodegeneration, J Neurosci 29, 12795-12801.

[16] Hamer, M., and Chida, Y. (2009) Physical activity and risk of neurodegenerative disease: a systematic review of prospective evidence, Psychol Med 39, 3-11.

[17] Chin-Chan, M., Navarro-Yepes, J., and Quintanilla-Vega, B. (2015) Environmental pollutants as risk factors for neurodegenerative disorders: Alzheimer and Parkinson diseases, Front Cell Neurosci 9, 124.

[18] Sharp, E. S., and Gatz, M. (2011) The relationship between education and dementia an updated systematic review, Alzheimer Dis Assoc Disord 25, 289. 
[19] Viña, J., and Lloret, A. (2010) Why women have more Alzheimer's disease than men: gender and mitochondrial toxicity of amyloid- $\beta$ peptide, J Alzheimers Dis 20, 527-533.

[20] Mazure, C. M., and Swendsen, J. (2016) Sex differences in Alzheimer's disease and other dementias, Lancet Neurol 15, 451.

[21] Lott, I. T., and Head, E. (2005) Alzheimer disease and Down syndrome: factors in pathogenesis, Neurobiol Aging 26, 383-389.

[22] Menéndez, M. (2005) Down syndrome, Alzheimer's disease and seizures, Brain Dev 27, 246-252.

[23] Gavett, B. E., Stern, R. A., Cantu, R. C., Nowinski, C. J., and McKee, A. C. (2010) Mild traumatic brain injury: a risk factor for neurodegeneration, Alzheimers Res Ther 2, 18.

[24] Mez, J., Daneshvar, D. H., Kiernan, P. T., Abdolmohammadi, B., Alvarez, V. E., Huber, B. R., Alosco, M. L., Solomon, T. M., Nowinski, C. J., and McHale, L. (2017) Clinicopathological evaluation of chronic traumatic encephalopathy in players of American football, JAMA 318, 360-370.

[25] Justin, B. N., Turek, M., and Hakim, A. M. (2013) Heart disease as a risk factor for dementia, Clin Epidemiol 5, 135.

[26] Kroner, Z. (2009) The relationship between Alzheimer's disease and diabetes: Type 3 diabetes?, Altern Med Rev 14, 373.

[27] Ascherio, A., and Schwarzschild, M. A. (2016) The epidemiology of Parkinson's disease: risk factors and prevention, Lancet Neurol 15, 1257-1272.

[28] Chiu, M.-J., Chen, T.-F., Yip, P.-K., Hua, M.-S., and Tang, L.-Y. (2006) Behavioral and psychologic symptoms in different types of dementia, J Formos Med Assoc 105, 556-562.

[29] Brettschneider, J., Del Tredici, K., Lee, V. M.-Y., and Trojanowski, J. Q. (2015) Spreading of pathology in neurodegenerative diseases: a focus on human studies, Nat Rev Neurosci 16, 109-120.

[30] Casey, D. A., Antimisiaris, D., and O'Brien, J. (2010) Drugs for Alzheimer's disease: are they effective?, Pharm Ther 35, 208.

[31] Mangialasche, F., Solomon, A., Winblad, B., Mecocci, P., and Kivipelto, M. (2010) Alzheimer's disease: clinical trials and drug development, Lancet Neurol 9, 702-716.

[32] Barnes, D. E., and Yaffe, K. (2011) The projected effect of risk factor reduction on Alzheimer's disease prevalence, Lancet Neurol 10, 819-828.

[33] Mayeux, R., and Stern, Y. (2012) Epidemiology of Alzheimer disease, Cold Spring Harb Perspect Med 2, a006239.

[34] Jack, C. R., Albert, M. S., Knopman, D. S., McKhann, G. M., Sperling, R. A., Carrillo, M. C., Thies, B., and Phelps, C. H. (2011) Introduction to the recommendations from the National Institute on Aging-Alzheimer's Association workgroups on diagnostic guidelines for Alzheimer's disease, Alzheimers Dement 7, 257-262.

[35] Mitchell, A. J., and Shiri-Feshki, M. (2009) Rate of progression of mild cognitive impairment to dementia - meta-analysis of 41 robust inception cohort studies, Acta Psychiatr Scand 119, 252-265.

[36] Frisoni, G. B., Fox, N. C., Jack, C. R., Scheltens, P., and Thompson, P. M. (2010) The clinical use of structural MRI in Alzheimer disease, Nat Rev Neurol 6, 67-77.

[37] Liu, C.-C., Kanekiyo, T., Xu, H., and Bu, G. (2013) Apolipoprotein E and Alzheimer disease: risk, mechanisms, and therapy, Nat Rev Neurol 9, 106-118.

[38] Kim, J., Basak, J. M., and Holtzman, D. M. (2009) The role of apolipoprotein E in Alzheimer's disease, Neuron 63, 287-303.

[39] Van Cauwenberghe, C., Van Broeckhoven, C., and Sleegers, K. (2015) The genetic landscape of Alzheimer disease: clinical implications and perspectives, Genet Med 18, 421-430.

[40] Cedazo-Minguez, A., and Winblad, B. (2010) Biomarkers for Alzheimer's disease and other forms of dementia: Clinical needs, limitations and future aspects, Exp Gerontol 45, 5-14.

[41] Humpel, C. (2011) Identifying and validating biomarkers for Alzheimer's disease, Trends Biotechnol 29, 26-32. 
[42] Mawuenyega, K. G., Sigurdson, W., Ovod, V., Munsell, L., Kasten, T., Morris, J. C., Yarasheski, K. E., and Bateman, R. J. (2010) Decreased clearance of CNS $\beta$-amyloid in Alzheimer's disease, Science 330, 1774-1774.

[43] Braak, H., and Del Tredici, K. (2011) Alzheimer's pathogenesis: is there neuron-to-neuron propagation?, Acta Neuropathol 121, 589-595.

[44] Pimplikar, S. W. (2009) Reassessing the amyloid cascade hypothesis of Alzheimer's disease, Int J Biochem Cell Biol 41, 1261-1268.

[45] Murphy, M. P., and LeVine III, H. (2010) Alzheimer's disease and the amyloid- $\beta$ peptide, J Alzheimers Dis 19, 311-323.

[46] Gendron, T. F., and Petrucelli, L. (2009) The role of tau in neurodegeneration, Mol Neurodegener 4, 13.

[47] Cohen, T. J., Guo, J. L., Hurtado, D. E., Kwong, L. K., Mills, I. P., Trojanowski, J. Q., and Lee, V. M. (2011) The acetylation of tau inhibits its function and promotes pathological tau aggregation, Nat Commun 2, 252.

[48] Serrano-Pozo, A., Frosch, M. P., Masliah, E., and Hyman, B. T. (2011) Neuropathological alterations in Alzheimer disease, Cold Spring Harbor Perspect Med 1, a006189.

[49] Braak, H., and Braak, E. (1991) Neuropathological stageing of Alzheimer-related changes, Acta Neuropathol 82, 239-259.

[50] Thal, D. R., Ghebremedhin, E., Orantes, M., and Wiestler, O. D. (2003) Vascular pathology in Alzheimer disease: correlation of cerebral amyloid angiopathy and arteriosclerosis/lipohyalinosis with cognitive decline, J Neuropathol Exp Neurol 62, 12871301.

[51] Vann Jones, S. A., and O'Brien, J. T. (2014) The prevalence and incidence of dementia with Lewy bodies: a systematic review of population and clinical studies, Psychol Med 44, 673-683.

[52] Zaccai, J., McCracken, C., and Brayne, C. (2005) A systematic review of prevalence and incidence studies of dementia with Lewy bodies, Age Ageing 34, 561-566.

[53] McKeith, I., Burn, D., Ballard, C., Collerton, D., Jaros, E., Morris, C., McLaren, A., Perry, E., Perry, R., and Piggott, M. (2003) Dementia with Lewy bodies, Semin Clin Neuropsychiatry, pp 46-57.

[54] Stefanis, L. (2012) $\alpha$-Synuclein in Parkinson's disease, Cold Spring Harbor Perspect Med 2, a009399.

[55] Deramecourt, V., Bombois, S., Maurage, C. A., Ghestem, A., Drobecq, H., Vanmechelen, E., Lebert, F., Pasquier, F., and Delacourte, A. (2006) Biochemical staging of synucleinopathy and amyloid deposition in dementia with Lewy bodies, J Neuropathol Exp Neurol 65, 278288.

[56] McKeith, I. (2004) Dementia with Lewy bodies, Dialogues Clin Neurosci 6, 333-341.

[57] Williams, M. M., Xiong, C., Morris, J. C., and Galvin, J. E. (2006) Survival and mortality differences between dementia with Lewy bodies vs Alzheimer disease, Neurology 67, 19351941.

[58] McKeith, I. G., Dickson, D. W., Lowe, J., Emre, M., O'brien, J., Feldman, H., Cummings, J., Duda, J., Lippa, C., and Perry, E. (2005) Diagnosis and management of dementia with Lewy bodies third report of the DLB consortium, Neurology 65, 1863-1872.

[59] Vieira, R. T., Caixeta, L., Machado, S., Silva, A. C., Nardi, A. E., Arias-Carrión, O., and Carta, M. G. (2013) Epidemiology of early-onset dementia: a review of the literature, Clin Pract Epidemiol Ment Health 9, 88.

[60] Warren, J. D., Rohrer, J. D., and Rossor, M. N. (2013) Frontotemporal dementia, BMJ 347, f4827.

[61] Bang, J., Spina, S., and Miller, B. L. (2015) Frontotemporal dementia, Lancet 386, 1672-1682.

[62] Rascovsky, K., Hodges, J. R., Knopman, D., Mendez, M. F., Kramer, J. H., Neuhaus, J., Van Swieten, J. C., Seelaar, H., Dopper, E. G., and Onyike, C. U. (2011) Sensitivity of revised diagnostic criteria for the behavioural variant of frontotemporal dementia, Brain 134, 24562477.

[63] T O'Brien, J., and Thomas, A. (2015) Vascular dementia, Lancet 386, 1698-1706. 
[64] Gorelick, P. B. (2004) Risk factors for vascular dementia and Alzheimer disease, Stroke 35, 26202622.

[65] Rohn, T. T. (2014) Is apolipoprotein E4 an important risk factor for vascular dementia?, Int J Clin Exp Pathol 7, 3504.

[66] Meireles, J., and Massano, J. (2012) Cognitive impairment and dementia in Parkinson's disease: clinical features, diagnosis, and management, Front Neurol 3.

[67] Aarsland, D., Zaccai, J., and Brayne, C. (2005) A systematic review of prevalence studies of dementia in Parkinson's disease, Mov Disord 20, 1255-1263.

[68] Savica, R., Grossardt, B. R., Bower, J. H., Boeve, B. F., Ahlskog, J. E., and Rocca, W. A. (2013) Incidence of dementia with Lewy bodies and Parkinson disease dementia, JAMA Neurol 70, 1396-1402.

[69] Chaudhuri, K. R., and Schapira, A. H. (2009) Non-motor symptoms of Parkinson's disease: dopaminergic pathophysiology and treatment, Lancet Neurol 8, 464-474.

[70] Stacy, M., Bowron, A., Guttman, M., Hauser, R., Hughes, K., Larsen, J. P., LeWitt, P., Oertel, W., Quinn, N., and Sethi, K. (2005) Identification of motor and nonmotor wearing-off in Parkinson's disease: comparison of a patient questionnaire versus a clinician assessment, Mov Disord 20, 726-733.

[71] Emre, M., Aarsland, D., Brown, R., Burn, D. J., Duyckaerts, C., Mizuno, Y., Broe, G. A., Cummings, J., Dickson, D. W., and Gauthier, S. (2007) Clinical diagnostic criteria for dementia associated with Parkinson's disease, Mov Disord 22, 1689-1707.

[72] Schneider, J. A., Arvanitakis, Z., Bang, W., and Bennett, D. A. (2007) Mixed brain pathologies account for most dementia cases in community-dwelling older persons, Neurology 69, 21972204.

[73] Jellinger, K., and Attems, J. (2007) Neuropathological evaluation of mixed dementia, J Neurol Sci 257, 80-87.

[74] Lim, A., Tsuang, D., Kukull, W., Nochlin, D., Leverenz, J., McCormick, W., Bowen, J., Teri, L., Thompson, J., and Peskind, E. R. (1999) Clinico-neuropathological correlation of Alzheimer's disease in a community-based case series, J Am Geriatr Soc 47, 564-569.

[75] Walker, Z., Possin, K. L., Boeve, B. F., and Aarsland, D. (2015) Lewy body dementias, Lancet 386, 1683-1697.

[76] Compta, Y., Parkkinen, L., O'sullivan, S. S., Vandrovcova, J., Holton, J. L., Collins, C., Lashley, T., Kallis, C., Williams, D. R., and de Silva, R. (2011) Lewy-and Alzheimer-type pathologies in Parkinson's disease dementia: which is more important?, Brain 134, 1493-1505.

[77] McKee, A. C., Cairns, N. J., Dickson, D. W., Folkerth, R. D., Keene, C. D., Litvan, I., Perl, D. P., Stein, T. D., Vonsattel, J.-P., and Stewart, W. (2016) The first NINDS/NIBIB consensus meeting to define neuropathological criteria for the diagnosis of chronic traumatic encephalopathy, Acta Neuropathol 131, 75-86.

[78] McKee, A. C., Cantu, R. C., Nowinski, C. J., Hedley-Whyte, E. T., Gavett, B. E., Budson, A. E., Santini, V. E., Lee, H.-S., Kubilus, C. A., and Stern, R. A. (2009) Chronic traumatic encephalopathy in athletes: progressive tauopathy after repetitive head injury, $J$ Neuropathol Exp Neurol 68, 709-735.

[79] Pradier, C., Sakarovitch, C., Le Duff, F., Layese, R., Metelkina, A., Anthony, S., Tifratene, K., and Robert, P. (2014) The mini mental state examination at the time of Alzheimer's disease and related disorders diagnosis, according to age, education, gender and place of residence: a cross-sectional study among the French National Alzheimer database, PloS ONE 9, e103630.

[80] Benson, A. D., Slavin, M. J., Tran, T.-T., Petrella, J. R., and Doraiswamy, P. M. (2005) Screening for early Alzheimer's disease: is there still a role for the Mini-Mental State Examination?, Prim Care Companion J Clin Psychiatry 7, 62.

[81] O'Bryant, S. E., Humphreys, J. D., Smith, G. E., Ivnik, R. J., Graff-Radford, N. R., Petersen, R. C., and Lucas, J. A. (2008) Detecting dementia with the mini-mental state examination in highly educated individuals, Arch Neurol 65, 963-967. 
[82] Cooper, S., and Greene, J. D. W. (2005) The clinical assessment of the patient with early dementia, J Neurol Neurosurg Psychiatry 76, v15-v24.

[83] Huang, W., Qiu, C., von Strauss, E., Winblad, B., and Fratiglioni, L. (2004) APOE genotype, family history of dementia, and Alzheimer disease risk: a 6-year follow-up study, Arch Neurol 61, 1930-1934.

[84] Ikonomovic, M. D., Klunk, W. E., Abrahamson, E. E., Mathis, C. A., Price, J. C., Tsopelas, N. D., Lopresti, B. J., Ziolko, S., Bi, W., and Paljug, W. R. (2008) Post-mortem correlates of in vivo PiB-PET amyloid imaging in a typical case of Alzheimer's disease, Brain 131, 1630-1645.

[85] Frisoni, G. B., Boccardi, M., Barkhof, F., Blennow, K., Cappa, S., Chiotis, K., Démonet, J.-F., Garibotto, V., Giannakopoulos, P., and Gietl, A. (2017) Strategic roadmap for an early diagnosis of Alzheimer's disease based on biomarkers, Lancet Neurol 16, 661-676.

[86] Okamura, N., and Yanai, K. (2017) Brain imaging: Applications of tau PET imaging, Nat Rev Neurol 13, 197-198.

[87] Ossenkoppele, R., Schonhaut, D. R., Schöll, M., Lockhart, S. N., Ayakta, N., Baker, S. L., O’Neil, J. P., Janabi, M., Lazaris, A., and Cantwell, A. (2016) Tau PET patterns mirror clinical and neuroanatomical variability in Alzheimer's disease, Brain 139, 1551-1567.

[88] Olsson, B., Lautner, R., Andreasson, U., Öhrfelt, A., Portelius, E., Bjerke, M., Hölttä, M., Rosén, C., Olsson, C., and Strobel, G. (2016) CSF and blood biomarkers for the diagnosis of Alzheimer's disease: a systematic review and meta-analysis, Lancet Neurol 15, 673-684.

[89] Blennow, K., Dubois, B., Fagan, A. M., Lewczuk, P., de Leon, M. J., and Hampel, H. (2015) Clinical utility of cerebrospinal fluid biomarkers in the diagnosis of early Alzheimer's disease, Alzheimers Dement 11, 58-69.

[90] Zetterberg, H., and Blennow, K. (2006) Plasma A $\beta$ in Alzheimer's disease-up or down?, Lancet Neurol 5, 638-639.

[91] Salvadores, N., Shahnawaz, M., Scarpini, E., Tagliavini, F., and Soto, C. (2014) Detection of misfolded $A \beta$ oligomers for sensitive biochemical diagnosis of Alzheimer's disease, Cell Rep 7, 261-268.

[92] Lui, J. K., Laws, S. M., Li, Q.-X., Villemagne, V. L., Ames, D., Brown, B., Bush, A. I., De Ruyck, K., Dromey, J., and Ellis, K. A. (2010) Plasma amyloid- $\beta$ as a biomarker in Alzheimer's disease: the AIBL study of aging, J Alzheimers Dis 20, 1233-1242.

[93] Abdullah, L., Paris, D., Luis, C., Quadros, A., Parrish, J., Valdes, L., Keegan, A. P., Mathura, V., Crawford, F., and Mullan, M. (2007) The influence of diagnosis, intra-and inter-person variability on serum and plasma $A \beta$ levels, Neurosci Lett 428, 53-58.

[94] Sundelöf, J., Giedraitis, V., Irizarry, M. C., Sundström, J., Ingelsson, E., Rönnemaa, E., Ärnlöv, J., Gunnarsson, M. D., Hyman, B. T., and Basun, H. (2008) Plasma $\beta$ amyloid and the risk of Alzheimer disease and dementia in elderly men: a prospective, population-based cohort study, Arch Neurol 65, 256-263.

[95] Choo, L. P., Wetzel, D. L., Halliday, W. C., Jackson, M., LeVine, S. M., and Mantsch, H. H. (1996) In situ characterization of beta-amyloid in Alzheimer's diseased tissue by synchrotron Fourier transform infrared microspectroscopy, Biophys J 71, 1672-1679.

[96] Leskovjan, A. C., Kretlow, A., and Miller, L. M. (2010) Fourier transform infrared imaging showing reduced unsaturated lipid content in the hippocampus of a mouse model of Alzheimer's disease, Anal Chem 82, 2711-2716.

[97] Carmona, P., Molina, M., López-Tobar, E., and Toledano, A. (2015) Vibrational spectroscopic analysis of peripheral blood plasma of patients with Alzheimer's disease, Anal Bioanal Chem 407, 7747-7756.

[98] Nabers, A., Ollesch, J., Schartner, J., Kötting, C., Genius, J., Hafermann, H., Klafki, H., Gerwert, K., and Wiltfang, J. (2016) Amyloid- $\beta$-secondary structure distribution in cerebrospinal fluid and blood measured by an immuno-infrared-sensor: A biomarker candidate for Alzheimer's disease, Anal Chem 88, 2755-2762. 
[99] Paraskevaidi, M., Morais, C. L. M., Lima, K. M. G., Snowden, J. S., Saxon, J. A., Richardson, A. M. T., Jones, M., Mann, D. M. A., Allsop, D., Martin-Hirsch, P. L., and Martin, F. L. (2017) Differential diagnosis of Alzheimer's disease using spectrochemical analysis of blood, Proc Natl Acad Sci USA 114, E7929-e7938.

[100] Paraskevaidi, M., Halliwell, D. E., Mann, D. M. A., Allsop, D., Martin-Hirsch, P. L., and Martin, F. L. (2018) Raman spectroscopy to diagnose Alzheimer's disease and dementia with Lewy bodies in blood, under review.

[101] Devitt, G., Howard, K., Mudher, A., and Mahajan, S. (2018) Raman Spectroscopy: An emerging tool in neurodegenerative disease research and diagnosis, ACS Chem Neurosci.

[102] Organization, W. H. (2016) World Health Statistics 2016: Monitoring Health for the SDGs Sustainable Development Goals, World Health Organization.

[103] Hye, A., Lynham, S., Thambisetty, M., Causevic, M., Campbell, J., Byers, H. L., Hooper, C., Rijsdijk, F., Tabrizi, S. J., Banner, S., Shaw, C. E., Foy, C., Poppe, M., Archer, N., Hamilton, G., Powell, J., Brown, R. G., Sham, P., Ward, M., and Lovestone, S. (2006) Proteome-based plasma biomarkers for Alzheimer's disease, Brain 129, 3042-3050.

[104] Montagne, A., Barnes, S. R., Sweeney, M. D., Halliday, M. R., Sagare, A. P., Zhao, Z., Toga, A. W., Jacobs, R. E., Liu, C. Y., and Amezcua, L. (2015) Blood-brain barrier breakdown in the aging human hippocampus, Neuron 85, 296-302.

[105] Saint-Aubert, L., Lemoine, L., Chiotis, K., Leuzy, A., Rodriguez-Vieitez, E., and Nordberg, A. (2017) Tau PET imaging: present and future directions, Mol Neurodegener 12, 19.

[106] Beach, T. G., Schneider, J. A., Sue, L. I., Serrano, G., Dugger, B. N., Monsell, S. E., and Kukull, W. (2014) Theoretical impact of Florbetapir (18F) amyloid imaging on diagnosis of alzheimer dementia and detection of preclinical cortical amyloid, J Neuropathol Exp Neurol 73, 948953.

[107] Richard, E., Schmand, B. A., Eikelenboom, P., and Van Gool, W. A. (2013) MRI and cerebrospinal fluid biomarkers for predicting progression to Alzheimer9s disease in patients with mild cognitive impairment: a diagnostic accuracy study, BMJ open 3, e002541.

[108] Neary, D., Snowden, J. S., Gustafson, L., Passant, U., Stuss, D., Black, S. a., Freedman, M., Kertesz, A., Robert, P., and Albert, M. (1998) Frontotemporal lobar degeneration A consensus on clinical diagnostic criteria, Neurology 51, 1546-1554.

[109] Román, G. C., Tatemichi, T. K., Erkinjuntti, T., Cummings, J., Masdeu, J., Garcia, J. a., Amaducci, L., Orgogozo, J.-M., Brun, A., and Hofman, A. (1993) Vascular dementia Diagnostic criteria for research studies: Report of the NINDS-AIREN International Workshop, Neurology 43, 250250.

[110] Mattsson, N., Andreasson, U., Zetterberg, H., Blennow, K., and for the Alzheimer's Disease Neuroimaging, I. (2017) Association of plasma neurofilament light with neurodegeneration in patients with alzheimer disease, JAMA Neurol 74, 557-566.

[111] Tatebe, H., Kasai, T., Ohmichi, T., Kishi, Y., Kakeya, T., Waragai, M., Kondo, M., Allsop, D., and Tokuda, T. (2017) Quantification of plasma phosphorylated tau to use as a biomarker for brain Alzheimer pathology: pilot case-control studies including patients with Alzheimer's disease and down syndrome, Mol Neurodegener 12, 63.

[112] Wolters, F. J., Koudstaal, P. J., Hofman, A., van Duijn, C. M., and Ikram, M. A. (2016) Serum apolipoprotein $\mathrm{E}$ is associated with long-term risk of Alzheimer's disease: The Rotterdam Study, Neurosci Lett 617, 139-142.

[113] Forlenza, O. V., Radanovic, M., Talib, L. L., Aprahamian, I., Diniz, B. S., Zetterberg, H., and Gattaz, W. F. (2015) Cerebrospinal fluid biomarkers in Alzheimer's disease: Diagnostic accuracy and prediction of dementia, Alzheimers Dement (Amst) 1, 455-463.

[114] Gonzalez-Dominguez, R., Garcia-Barrera, T., and Gomez-Ariza, J. L. (2015) Metabolite profiling for the identification of altered metabolic pathways in Alzheimer's disease, $J$ Pharm Biomed Anal 107, 75-81. 
[115] Hye, A., Riddoch-Contreras, J., Baird, A. L., Ashton, N. J., Bazenet, C., Leung, R., Westman, E., Simmons, A., Dobson, R., Sattlecker, M., Lupton, M., Lunnon, K., Keohane, A., Ward, M., Pike, I., Zucht, H. D., Pepin, D., Zheng, W., Tunnicliffe, A., Richardson, J., Gauthier, S., Soininen, H., Kloszewska, I., Mecocci, P., Tsolaki, M., Vellas, B., and Lovestone, S. (2014) Plasma proteins predict conversion to dementia from prodromal disease, Alzheimers Dement 10, 799-807.e792.

[116] Mapstone, M., Cheema, A. K., Fiandaca, M. S., Zhong, X., Mhyre, T. R., MacArthur, L. H., Hall, W. J., Fisher, S. G., Peterson, D. R., Haley, J. M., Nazar, M. D., Rich, S. A., Berlau, D. J., Peltz, C. B., Tan, M. T., Kawas, C. H., and Federoff, H. J. (2014) Plasma phospholipids identify antecedent memory impairment in older adults, Nat Med 20, 415-418.

[117] Chiu, M. J., Yang, S. Y., Horng, H. E., Yang, C. C., Chen, T. F., and Chieh, J. J. (2013) Combined plasma biomarkers for diagnosing mild cognition impairment and Alzheimer's disease, ACS Chem Neurosci 4.

[118] Trushina, E., Dutta, T., Persson, X.-M. T., Mielke, M. M., and Petersen, R. C. (2013) Identification of altered metabolic pathways in plasma and CSF in mild cognitive impairment and Alzheimer's disease using metabolomics, PIOS ONE 8, e63644.

[119] Zetterberg, H., Wilson, D., Andreasson, U., Minthon, L., Blennow, K., Randall, J., and Hansson, O. (2013) Plasma tau levels in Alzheimer's disease, Alzheimers Res Ther 5, 9.

[120] Blennow, K., Hampel, H., Weiner, M., and Zetterberg, H. (2010) Cerebrospinal fluid and plasma biomarkers in Alzheimer disease, Nat Rev Neurol 6.

[121] Brys, M., Pirraglia, E., Rich, K., Rolstad, S., Mosconi, L., Switalski, R., Glodzik-Sobanska, L., De Santi, S., Zinkowski, R., and Mehta, P. (2009) Prediction and longitudinal study of CSF biomarkers in mild cognitive impairment, Neurobiol Aging 30, 682-690.

[122] Lambert, J. C., Heath, S., Even, G., Campion, D., Sleegers, K., Hiltunen, M., Combarros, O., Zelenika, D., Bullido, M. J., Tavernier, B., Letenneur, L., Bettens, K., Berr, C., Pasquier, F., Fievet, N., Barberger-Gateau, P., Engelborghs, S., De Deyn, P., Mateo, I., Franck, A., Helisalmi, S., Porcellini, E., Hanon, O., de Pancorbo, M. M., Lendon, C., Dufouil, C., Jaillard, C., Leveillard, T., Alvarez, V., Bosco, P., Mancuso, M., Panza, F., Nacmias, B., Bossu, P., Piccardi, P., Annoni, G., Seripa, D., Galimberti, D., Hannequin, D., Licastro, F., Soininen, H., Ritchie, K., Blanche, H., Dartigues, J. F., Tzourio, C., Gut, I., Van Broeckhoven, C., Alperovitch, A., Lathrop, M., and Amouyel, P. (2009) Genome-wide association study identifies variants at CLU and CR1 associated with Alzheimer's disease, Nat Genet 41, 1094-1099.

[123] Lopez, O., Kuller, L., Mehta, P., Becker, J., Gach, H., Sweet, R., Chang, Y., Tracy, R., and DeKosky, S. (2008) Plasma amyloid levels and the risk of $A D$ in normal subjects in the Cardiovascular Health Study, Neurology 70, 1664-1671.

[124] Roher, A. E., Esh, C. L., Kokjohn, T. A., Castaño, E. M., Van Vickle, G. D., Kalback, W. M., Patton, R. L., Luehrs, D. C., Daugs, I. D., and Kuo, Y.-M. (2009) Amyloid beta peptides in human plasma and tissues and their significance for Alzheimer's disease, Alzheimers Dement 5, 1829.

[125] Bian, H., Van Swieten, J., Leight, S., Massimo, L., Wood, E., Forman, M., Moore, P., De Koning, I., Clark, C., and Rosso, S. (2008) CSF biomarkers in frontotemporal lobar degeneration with known pathology, Neurology 70, 1827-1835.

[126] Blasko, I., Jellinger, K., Kemmler, G., Krampla, W., Jungwirth, S., Wichart, I., Tragl, K. H., and Fischer, P. (2008) Conversion from cognitive health to mild cognitive impairment and Alzheimer's disease: prediction by plasma amyloid beta 42 , medial temporal lobe atrophy and homocysteine, Neurobiol Aging 29, 1-11.

[127] Schupf, N., Tang, M. X., Fukuyama, H., Manly, J., Andrews, H., Mehta, P., Ravetch, J., and Mayeux, R. (2008) Peripheral A $\beta$ subspecies as risk biomarkers of Alzheimer's disease, Proc Natl Acad Sci USA 105, 14052-14057. 
[128] Ewers, M., Buerger, K., Teipel, S., Scheltens, P., Schröder, J., Zinkowski, R., Bouwman, F., Schönknecht, P., Schoonenboom, N., and Andreasen, N. (2007) Multicenter assessment of CSF-phosphorylated tau for the prediction of conversion of MCI, Neurology 69, 2205-2212.

[129] Graff-Radford, N. R., Crook, J. E., Lucas, J., Boeve, B. F., Knopman, D. S., Ivnik, R. J., Smith, G. E., Younkin, L. H., Petersen, R. C., and Younkin, S. G. (2007) Association of low plasma $A \beta 42 / A \beta 40$ ratios with increased imminent risk for mild cognitive impairment and Alzheimer disease, Arch Neurol 64, 354-362.

[130] Hansson, O., Zetterberg, H., Buchhave, P., Londos, E., Blennow, K., and Minthon, L. (2006) Association between CSF biomarkers and incipient Alzheimer's disease in patients with mild cognitive impairment: a follow-up study, Lancet Neurol 5.

[131] Pesaresi, M., Lovati, C., Bertora, P., Mailland, E., Galimberti, D., Scarpini, E., Quadri, P., Forloni, G., and Mariani, C. (2006) Plasma levels of beta-amyloid (1-42) in Alzheimer's disease and mild cognitive impairment, Neurobiol Aging 27, 904-905.

[132] van Oijen, M., Hofman, A., Soares, H. D., Koudstaal, P. J., and Breteler, M. M. (2006) Plasma A $\beta$ 1-40 and $A \beta$ 1-42 and the risk of dementia: a prospective case-cohort study, Lancet Neurol 5, 655-660.

[133] Rüetschi, U., Zetterberg, H., Podust, V. N., Gottfries, J., Li, S., Simonsen, A. H., McGuire, J., Karlsson, M., Rymo, L., and Davies, H. (2005) Identification of CSF biomarkers for frontotemporal dementia using SELDI-TOF, Exp Neurol 196, 273-281.

[134] Sobów, T., Flirski, M., Kloszewska, I., and Liberski, P. P. (2005) Plasma levels of Ab peptides are altered in amnestic mild cognitive impairment but not in sporadic Alzheimer s disease, Acta Neurobiol Exp 65, 117-124.

[135] Assini, A., Cammarata, S., Vitali, A., Colucci, M., Giliberto, L., Borghi, R., Inglese, M., Volpe, S., Ratto, S., and Dagna-Bricarelli, F. (2004) Plasma levels of amyloid $\beta$-protein 42 are increased in women with mild cognitive impairment, Neurology 63, 828-831.

[136] Hampel, H., Mitchell, A., Blennow, K., Frank, R., Brettschneider, S., Weller, L., and Möller, H.-J. (2004) Core biological marker candidates of Alzheimer's disease-perspectives for diagnosis, prediction of outcome and reflection of biological activity, J Neural Transm 111, 247-272.

[137] Fukumoto, H., Tennis, M., Locascio, J. J., Hyman, B. T., Growdon, J. H., and Irizarry, M. C. (2003) Age but not diagnosis is the main predictor of plasma amyloid $\beta$-protein levels, Arch Neurol 60, 958-964.

[138] Zetterberg, H., Wahlund, L.-O., and Blennow, K. (2003) Cerebrospinal fluid markers for prediction of Alzheimer's disease, Neurosci Lett 352, 67-69.

[139] Mehta, P. D., Pirttilä, T., Mehta, S. P., Sersen, E. A., Aisen, P. S., and Wisniewski, H. M. (2000) Plasma and cerebrospinal fluid levels of amyloid $\beta$ proteins 1-40 and 1-42 in Alzheimer disease, Arch Neurol 57, 100-105.

[140] Vanderstichele, H., Kerschaver, E. V., Hesse, C., Davidsson, P., Buyse, M.-A., Andreasen, N., Minthon, L., Wallin, A., Blennow, K., and Vanmechelen, E. (2000) Standardization of measurement of $\beta$-amyloid (1-42) in cerebrospinal fluid and plasma, Amyloid 7, 245-258.

[141] Andreasen, N., Hesse, C., Davidsson, P., Minthon, L., Wallin, A., Winblad, B., Vanderstichele, H., Vanmechelen, E., and Blennow, K. (1999) Cerebrospinal fluid $\beta$-amyloid (1-42) in Alzheimer disease: differences between early-and late-onset Alzheimer disease and stability during the course of disease, Arch Neurol 56, 673-680.

[142] Kanai, M., Matsubara, E., Isoe, K., Urakami, K., Nakashima, K., Arai, H., Sasaki, H., Abe, K., Iwatsubo, T., and Kosaka, T. (1998) Longitudinal study of cerebrospinal fluid levels of tau, A $1-40$, and Aß1-42 (43) in Alzheimer's disease: a study in Japan, Ann Neurol 44, 17-26.

[143] Motter, n., Vigo-Pelfrey, C., Kholodenko, D., Barbour, R., Johnson-Wood, K., Galasko, D., Chang, L., Miller, B., Clark, C., and Green, R. (1995) Reduction of $\beta$-amyloid peptide42 in the cerebrospinal fluid of patients with Alzheimer's disease, Ann Neurol 38, 643-648.

[144] Huang, C.-C., and Isidoro, C. (2017) Raman Spectrometric Detection Methods for Early and Non-Invasive Diagnosis of Alzheimer's Disease, J Alzheimers Dis, 1-12. 
[145] Michael, R., Lenferink, A., Vrensen, G. F., Gelpi, E., Barraquer, R. I., and Otto, C. (2017) Hyperspectral Raman imaging of neuritic plaques and neurofibrillary tangles in brain tissue from Alzheimer's disease patients, Sci Rep 7, 15603.

[146] Mordechai, S., Shufan, E., Porat Katz, B. S., and Salman, A. (2017) Early diagnosis of Alzheimer's disease using infrared spectroscopy of isolated blood samples followed by multivariate analyses, Analyst.

[147] Kiskis, J., Fink, H., Nyberg, L., Thyr, J., Li, J.-Y., and Enejder, A. (2015) Plaque-associated lipids in Alzheimer's diseased brain tissue visualized by nonlinear microscopy, Sci Rep 5, 13489.

[148] Demeritte, T., Viraka Nellore, B. P., Kanchanapally, R., Sinha, S. S., Pramanik, A., Chavva, S. R., and Ray, P. C. (2015) Hybrid graphene oxide based plasmonic-magnetic multifunctional nanoplatform for selective separation and label-free identification of Alzheimer's disease biomarkers, ACS Appl Mater Interfaces 7, 13693-13700.

[149] Ryzhikova, E., Kazakov, O., Halamkova, L., Celmins, D., Malone, P., Molho, E., Zimmerman, E. A., and Lednev, I. K. (2015) Raman spectroscopy of blood serum for Alzheimer's disease diagnostics: specificity relative to other types of dementia, J Biophotonics 8, 584-596.

[150] Magierski, R., and Sobow, T. (2014) Magnetic resonance spectroscopy in the diagnosis of dementia with Lewy bodies, BioMed Res Int 2014.

[151] Carmona, P., Molina, M., Calero, M., Bermejo-Pareja, F., Martinez-Martin, P., and Toledano, A. (2013) Discrimination analysis of blood plasma associated with Alzheimer's disease using vibrational spectroscopy, J Alzheimers Dis 34, 911-920.

[152] Luo, Y., Du, Z., Yang, Y., Chen, P., Tian, Q., Shang, X., Liu, Z., Yao, X., Wang, J., and Wang, X. (2013) Laser Raman detection of platelets for early and differential diagnosis of Alzheimer's disease based on an adaptive Gaussian process classification algorithm, Laser Phys 23, 045603.

[153] Chen, P., Tian, Q., Baek, S., Shang, X., Park, A., Liu, Z., Yao, X., Wang, J., Wang, X., and Cheng, Y. (2011) Laser Raman detection of platelet as a non-invasive approach for early and differential diagnosis of Alzheimer's disease, Laser Phys Lett 8, 547.

[154] Atkins, C. G., Buckley, K., Blades, M. W., and Turner, R. F. (2017) Raman Spectroscopy of Blood and Blood Components, App/ Spectrosc 71, 767-793.

[155] Burns, D. H., Rosendahl, S., Bandilla, D., Maes, O. C., Chertkow, H. M., and Schipper, H. M. (2009) Near-infrared spectroscopy of blood plasma for diagnosis of sporadic Alzheimer's disease, J Alzheimers Dis 17, 391-397.

[156] Chen, P., Shen, A., Zhao, W., Baek, S.-J., Yuan, H., and Hu, J. (2009) Raman signature from brain hippocampus could aid Alzheimer's disease diagnosis, Appl Opt 48, 4743-4748.

[157] Peuchant, E., Richard-Harston, S., Bourdel-Marchasson, I., Dartigues, J. F., Letenneur, L., Barberger-Gateau, P., Arnaud-Dabernat, S., and Daniel, J. Y. (2008) Infrared spectroscopy: a reagent-free method to distinguish Alzheimer's disease patients from normal-aging subjects, Transl Res 152, 103-112.

[158] Kantarci, K., Petersen, R. C., Boeve, B. F., Knopman, D. S., Tang-Wai, D. F., O’Brien, P. C., Weigand, S. D., Edland, S. D., Smith, G. E., and Ivnik, R. J. (2004) 1H MR spectroscopy in common dementias, Neurology 63, 1393-1398. 
977 Table 1: Biomarkers for the diagnosis of dementia subtypes.
Study
Technique
Type of
Dementia
Sample
Outcome/Accuracy

Imaging Tests

\begin{tabular}{|c|c|c|c|c|}
\hline \multirow[t]{3}{*}{ Frisoni, $2017^{85}$} & MRI & $\mathrm{AD}$ & $\begin{array}{l}\text { In vivo } \\
\text { imaging }\end{array}$ & $\begin{array}{l}\text { Decreased volume of hippocampus } \\
\& \text { temporal lobe structures due to } \\
\text { tissue loss \& neurodegeneration }\end{array}$ \\
\hline & ${ }^{18} \mathrm{FDG}-\mathrm{PET}$ & $\mathrm{AD}$ & $\begin{array}{l}\text { In vivo } \\
\text { imaging }\end{array}$ & $\begin{array}{c}\text { Decreased uptake due to glucose } \\
\text { hypometabolism \& } \\
\text { neurodegeneration }\end{array}$ \\
\hline & Amyloid PET & $\mathrm{AD}$ & $\begin{array}{l}\text { In vivo } \\
\text { imaging }\end{array}$ & $\begin{array}{l}\text { Increased binding due to } A \beta \text { in the } \\
\text { cortex }\end{array}$ \\
\hline Saint-Aubert, 2017105 & Tau PET & $\begin{array}{l}\text { AD, FTLD, } \\
\text { DLB }\end{array}$ & $\begin{array}{l}\text { In vivo } \\
\text { imaging }\end{array}$ & $\begin{array}{l}\text { In contrast to } \mathrm{A} \beta \text { plaques, tau protein } \\
\text { aggregates primarily intracellularly } \\
\text { rendering it difficult to access in } \\
\text { vivo. Novel ( } \sim 5 \text { yrs) tau PET tracers } \\
\text { show promise for the discrimination } \\
\text { between neurodegenerative diseases } \\
\text { and monitoring of disease } \\
\text { progression; more research is } \\
\text { required as, despite promising, it has } \\
\text { been suggested that the tracer might } \\
\text { not bind substantially to the tau } \\
\text { burden }\end{array}$ \\
\hline \multirow[t]{4}{*}{ McKeith, $2017^{6}$} & SPECT/PET & $\mathrm{AD}, \mathrm{DLB}$ & $\begin{array}{l}\text { In vivo } \\
\text { imaging }\end{array}$ & $\begin{array}{c}\text { Reduced DAT uptake in basal } \\
\text { ganglia provided } 78 \% \text { sensitivity } \\
\text { and } 90 \% \text { specificity }\end{array}$ \\
\hline & $\begin{array}{l}{ }^{123} \text { Iodine- } \\
\text { MIBG } \\
\text { scintigraphy }\end{array}$ & $\mathrm{AD}, \mathrm{DLB}$ & $\begin{array}{l}\text { In vivo } \\
\text { imaging }\end{array}$ & $\begin{array}{c}\text { Reduced uptake on MIBG } \\
\text { myocardial scintigraphy was } \\
\text { reported in LB disease; sens (69\%) } \\
\text { and specif (87\%) values that } \\
\text { discriminated between probable DLB } \\
\text { and AD, increased to } 77 \% \text { and } 94 \% \\
\text { in milder cases }\end{array}$ \\
\hline & CT/MRI & $\mathrm{AD}, \mathrm{DLB}$ & $\begin{array}{l}\text { In vivo } \\
\text { imaging }\end{array}$ & $\begin{array}{l}\text { Relative preservation of medial } \\
\text { temporal lobe (MTL) structures on } \\
\text { CT/MRI scan; in contrast to AD, } \\
\text { DLB patients do not show a great } \\
\text { atrophy of MTL; } 64 \% \text { sens and } 68 \% \\
\text { specif were the values for separating } \\
\text { AD from DLB }\end{array}$ \\
\hline & Amyloid PET & $\mathrm{AD}, \mathrm{DLB}$ & $\begin{array}{l}\text { In vivo } \\
\text { imaging }\end{array}$ & $\begin{array}{l}\text { Increased } A \beta \text { deposition in }>50 \% \\
\text { DLB patients; limited value in } \\
\text { differentiating from AD; combining } \\
\text { biomarkers could improve } \\
\text { differential diagnosis }\end{array}$ \\
\hline
\end{tabular}




\begin{tabular}{|c|c|c|c|c|}
\hline & Tau PET & AD, DLB & $\begin{array}{l}\text { In vivo } \\
\text { imaging }\end{array}$ & $\begin{array}{l}\text { Tau PET imaging, along with MTL } \\
\text { atrophy, may indicate coexisting AD } \\
\text { pathology in DLB }\end{array}$ \\
\hline Ossenkoppele, $2016^{87}$ & $\begin{array}{l}\text { Tau, A } \beta \text { and } \\
{ }^{18} \text { FDG PET }\end{array}$ & $\mathrm{AD}$ & $\begin{array}{l}\text { In vivo } \\
\text { imaging }\end{array}$ & $\begin{array}{c}\text { Tau imaging, in contrast to } \mathrm{A} \beta \text {, } \\
\text { showed a strong regional association } \\
\text { with clinical and anatomical } \\
\text { heterogeneity in } \mathrm{AD} \text {; results from a } \\
\text { novel PET tracer were promising but } \\
\text { still preliminary, requiring further } \\
\text { research }\end{array}$ \\
\hline Beach, $2014^{106}$ & Amyloid PET & $\mathrm{AD}$ & $\begin{array}{l}\text { In vivo } \\
\text { imaging }\end{array}$ & $\begin{array}{l}\text { The diagnostic accuracy of a positive } \\
\text { A } \beta \text { scan was estimated at between } \\
69 \%-95 \% \text { sens and } 83 \%-89 \% \text { specif. }\end{array}$ \\
\hline Richard, $2013^{107}$ & MRI & MCI & $\begin{array}{l}\text { In vivo } \\
\text { imaging }\end{array}$ & $\begin{array}{l}\text { After administration of a short } \\
\text { memory test, the added improvement } \\
\text { in classification, coming from an } \\
\text { MRI, was only }+1.1 \% \text {, showing it } \\
\text { does not substantially affect the } \\
\text { diagnostic accuracy for predicting } \\
\text { progression in MCI patients; the } \\
\text { study highlights the importance of } \\
\text { the order of different tests when } \\
\text { assessing cognitive complaints }\end{array}$ \\
\hline Frisoni, $2010^{36}$ & MRI & $\mathrm{AD}$ & $\begin{array}{l}\text { In vivo } \\
\text { imaging }\end{array}$ & $\begin{array}{l}\text { Atrophy of medial temporal } \\
\text { structures is a valid biomarker of AD } \\
\text { and its progression; MRI is also a } \\
\text { partially validated candidate marker } \\
\text { for MCI and non-AD dementias }\end{array}$ \\
\hline McKeith, $2005^{58}$ & MRI & DLB & $\begin{array}{l}\text { In vivo } \\
\text { imaging }\end{array}$ & $\begin{array}{c}\text { Preserved medial temporal lobes } \\
\text { (relative to AD) }\end{array}$ \\
\hline Neary, $1998^{108}$ & MRI & FTLD & $\begin{array}{l}\text { In vivo } \\
\text { imaging }\end{array}$ & Focal frontal or temporal atrophy \\
\hline Roman, $1993^{109}$ & MRI & $\mathrm{VaD}$ & $\begin{array}{l}\text { In vivo } \\
\text { imaging }\end{array}$ & $\begin{array}{l}\text { Strategic infarct or extensive white } \\
\text { matter changes }\end{array}$ \\
\hline
\end{tabular}

Biomarker Tests

\begin{tabular}{c|c|c|c|c}
\hline Frisoni, 2017 ${ }^{85}$ & Proteomics & AD & CSF & $\begin{array}{c}\text { Decreased A } \beta 42 \text { or } \mathrm{A} \beta 42: \mathrm{A} \beta 40 \text { ratio } \\
\text { due to abnormal A } \beta \text { metabolism; } \\
\text { increased T-tau and P-tau due to } \\
\text { neuronal damage and accumulation } \\
\text { of tau }\end{array}$ \\
\hline Mattsson, 2017 ${ }^{110}$ & Proteomics & AD, MCI & $\begin{array}{c}\text { CSF \& } \\
\text { Blood } \\
\text { Plasma }\end{array}$ & $\begin{array}{c}\text { Plasma NFL was correlated with } \\
\text { CSF NFL and was increased in MCI } \\
\text { and AD when compared to HC; } \text { high }\end{array}$ \\
\hline
\end{tabular}




\begin{tabular}{|c|c|c|c|c|}
\hline & & & & $\begin{array}{l}\text { NFL levels were correlated with poor } \\
\text { cognition and AD-related atrophy; } \\
\text { diagnostic accuracy was } 87 \% \text {; } \\
\text { however, plasma NFL levels are } \\
\text { increased in other neurological } \\
\text { disorders too and thus, could not be } \\
\text { used for differential diagnosis of AD }\end{array}$ \\
\hline McKeith, $2017^{6}$ & Proteomics & DLB & $\begin{array}{l}\text { CSF, blood, } \\
\text { peripheral } \\
\text { tissue }\end{array}$ & $\begin{array}{l}\text { Biomarkers for DLB are elusive and } \\
\text { the understanding of the core } \\
\text { biomarkers remains limited; CSF } \alpha \text { - } \\
\text { synuclein is not yet proven as a } \\
\text { biomarker, while A } \beta \text { and tau may be } \\
\text { more useful in detecting coexisting } \\
\text { AD }\end{array}$ \\
\hline Tatebe, $2017^{111}$ & Proteomics & $\mathrm{AD}, \mathrm{VaD}$ & $\begin{array}{l}\text { Blood } \\
\text { Plasma }\end{array}$ & $\begin{array}{c}\text { Plasma levels of P-tau181 were } \\
\text { significantly higher in AD than in } \\
\text { HC, providing } 60 \% \text { sens and } 86 \% \\
\text { specif; P-tau181 levels in AD and } \\
\text { VaD were significantly correlated } \\
\text { with those in CSF; further study was } \\
\text { suggested to validate the preliminary } \\
\text { results }\end{array}$ \\
\hline Olsson, $2016^{88}$ & Proteomics & $\mathrm{AD}$ & $\begin{array}{c}\text { CSF \& } \\
\text { Blood } \\
\text { serum/plasm } \\
\text { a }\end{array}$ & $\begin{array}{c}\text { The core CSF biomarkers for } \\
\text { neurodegeneration (T-tau, P-tau and } \\
\text { A } \beta 42 \text { ), CSF NFL and plasma T-tau } \\
\text { were associated with AD; the core } \\
\text { biomarkers were strongly associated } \\
\text { with MCI due to AD; promising CSF } \\
\text { biomarkers also included NSE, VLP- } \\
\text { 1, HFBP and YKL-40; plasma A } \beta 42 \\
\text { and A } \beta 40 \text { were not strongly } \\
\text { associated with AD }\end{array}$ \\
\hline Wolters, $2016^{112}$ & Proteomics & $\mathrm{AD}$ & Blood Serum & $\begin{array}{l}\text { APOE associated with long-term risk } \\
\text { of AD in general population; } \\
\text { additional value was limited }\end{array}$ \\
\hline Forlenza, $2015^{113}$ & Proteomics & $\mathrm{AD}$ & $\mathrm{CSF}$ & $\begin{array}{l}\mathrm{A} \beta 42 \text { levels showed } 89 \% \text { sens and } \\
70 \% \text { specif; T-tau levels showed } \\
82 \% \text { sens and } 67 \% \text { specif; P-tau } \\
\text { levels showed } 83 \% \text { sens and } 49 \% \\
\text { specif; } \mathrm{A} \beta_{42}: \mathrm{P} \text {-tau ratio showed } 88 \% \\
\text { sens and } 78 \% \text { specif; } \mathrm{A} \beta_{42}: \mathrm{T} \text {-tau } \\
\text { ratio showed } 80 \% \text { sens and } 80 \% \\
\text { specif; combining } \mathrm{A} \beta_{42} \text { and } \mathrm{A} \beta_{42}: \mathrm{P}- \\
\text { tau ratio was able to predict the } \\
\text { conversion in } 2 \text { yrs }\end{array}$ \\
\hline $\begin{array}{l}\text { González-Domínguez, } \\
2015^{114}\end{array}$ & Metabolomics & $\mathrm{AD}$ & Blood Serum & $\begin{array}{l}\text { Alterations in the levels of } 23 \\
\text { metabolites were detected in AD } \\
\text { patients; metabolic pathway analysis } \\
\text { showed different impairments such }\end{array}$ \\
\hline
\end{tabular}




\begin{tabular}{|c|c|c|c|c|}
\hline & & & & $\begin{array}{c}\text { as hypometabolism, oxidative stress, } \\
\text { hyperammonemia and others }\end{array}$ \\
\hline Hye, $2014^{115}$ & Proteomics & $\mathrm{AD}, \mathrm{MCI}$ & $\begin{array}{l}\text { Blood } \\
\text { Plasma }\end{array}$ & $\begin{array}{l}\text { Sixteen proteins correlated with } \\
\text { disease severity and cognitive } \\
\text { decline; strongest associations were } \\
\text { in the MCI group with a panel of } 10 \\
\text { proteins predicting progression to } \\
\text { AD with } 85 \% \text { sens and } 88 \% \text { specif }\end{array}$ \\
\hline Mapstone, $2014^{116}$ & Lipidomics & $\mathrm{AD}$ & $\begin{array}{l}\text { Blood } \\
\text { Plasma }\end{array}$ & $\begin{array}{l}\text { In a 5-yr observational study, a panel } \\
\text { of ten lipids was shown to predict } \\
\text { phenoconversion to either amnestic } \\
\text { MCI or AD within a } 2-3 \text { yr. } \\
\text { timeframe; accuracy was found } 90 \%\end{array}$ \\
\hline Chiu, $2013^{117}$ & Proteomics & $\mathrm{AD}, \mathrm{MCI}$ & $\begin{array}{l}\text { Blood } \\
\text { Plasma }\end{array}$ & $\begin{array}{l}\mathrm{A} \beta 42 \text { and tau protein are significantly } \\
\text { lower in the HC group; } \\
\text { differentiation of MCI from AD was } \\
\text { achieved with } ~ 90 \% \text { accuracy; } \\
\text { combined biomarkers differentiate } \\
\text { HC from MCI and AD }\end{array}$ \\
\hline Trushina, $2013^{118}$ & Metabolomics & $\mathrm{AD}, \mathrm{MCI}$ & $\begin{array}{c}\text { CSF \& } \\
\text { Blood } \\
\text { Plasma }\end{array}$ & $\begin{array}{c}\text { Researchers found } 23 \text { altered } \\
\text { pathways in plasma and } 20 \text { in CSF } \\
\text { after the comparison of MCI versus } \\
\text { HC; the number of affected pathways } \\
\text { increased with disease severity; } \\
\text { affected pathways included energy } \\
\text { metabolism, mitochondrial function, } \\
\text { lipid biosynthesis and others; data } \\
\text { from this study suggested that } \\
\text { metabolomics could reveal early } \\
\text { disease mechanisms shared in } \\
\text { progression from HC to MCI and } \\
\text { AD }\end{array}$ \\
\hline Richard, $2013{ }^{107}$ & Proteomics & MCI & CSF & $\begin{array}{l}\text { After administration of a short } \\
\text { memory test, the added improvement } \\
\text { in classification, coming from a CSF } \\
\text { test (P-tau:A } \beta \text { ratio), was }-2.2 \% \text {, } \\
\text { showing it does not improve the } \\
\text { diagnostic accuracy for predicting } \\
\text { progression in MCI patients; the } \\
\text { study highlights the importance of } \\
\text { the order of different tests when } \\
\text { assessing cognitive complaints }\end{array}$ \\
\hline Zetterberg, $2013^{119}$ & Proteomics & $\mathrm{AD}, \mathrm{MCI}$ & $\begin{array}{c}\text { CSF \& } \\
\text { Blood } \\
\text { Plasma }\end{array}$ & $\begin{array}{l}\text { Tau levels in AD plasma were } \\
\text { increased when compared to MCI } \\
\text { and HC but with overlapping ranges } \\
\text { across the groups which diminishes } \\
\text { its utility as a diagnostic test; there } \\
\text { was also no correlation between } \\
\text { plasma tau and CSF tau which may }\end{array}$ \\
\hline
\end{tabular}




\begin{tabular}{|c|c|c|c|c|}
\hline & & & & $\begin{array}{l}\text { be due to its clearance from the } \\
\text { bloodstream (within } 24 \mathrm{hrs} \text { ) }\end{array}$ \\
\hline Blennow, $2010^{120}$ & Proteomics & $\mathrm{AD}$ & $\begin{array}{l}\text { CSF \& } \\
\text { Blood } \\
\text { Plasma }\end{array}$ & $\begin{array}{l}\text { CSF A } \beta_{42} \text { level is reduced in } \mathrm{AD} \text { and } \\
\text { prodromal } \mathrm{AD} \text {; CSF P-tau and T-tau } \\
\text { levels are increased in } \mathrm{AD} \text { and } \\
\text { prodromal } \mathrm{AD} \text { and are indicative of } \\
\text { tau phosphorylation and neuronal } \\
\text { degeneration, respectively; a panel of } \\
18 \text { plasma proteins has been reported } \\
\text { to diagnose \& predict AD in MCI; } \\
\text { contradictory results in plasma } \mathrm{A} \beta 42 \\
\text { or A } \beta_{40} \text { may reflect that peripheral } \\
\text { plasma does not reflect } \mathrm{A} \beta \\
\text { metabolism; plasma levels of } \\
\text { complement factor H (CFH) and } \\
\text { alpha-2-macroglobulin }(\mathrm{A} 2 \mathrm{M}) \text { were } \\
\text { increased in AD }\end{array}$ \\
\hline Cedazo-Minguez, $2010^{40}$ & Proteomics & $\mathrm{AD}$ & $\begin{array}{l}\text { Blood } \\
\text { Plasma }\end{array}$ & $\begin{array}{l}\text { Plasma total } A \beta \text { or } A \beta_{42} \text { levels were } \\
\text { found increased in familial AD but } \\
\text { the results were not consistent in } \\
\text { sporadic } A D ; \text { elevated } A \beta_{42} \text { levels, } \\
\text { low levels of } A \beta_{42} \text { or a reduced } A \beta_{42} / \\
A \beta_{40} \text { ratio may indicate the } \\
\text { conversion from HC to MCI or AD }\end{array}$ \\
\hline Lui, $2010^{92}$ & Proteomics & $\mathrm{AD}$ & $\begin{array}{c}\text { Blood } \\
\text { Plasma }\end{array}$ & $\begin{array}{l}\text { Lower } A \beta_{42}: A \beta_{40} \text { ratio in } A D ; A \beta_{42} \\
\quad \text { reduction in MCI and } A D\end{array}$ \\
\hline Brys, $2009^{121}$ & Proteomics & $\mathrm{AD}, \mathrm{MCI}$ & $\mathrm{CSF}$ & $\begin{array}{l}\text { P-tau } 231 \text { was the strongest predictor } \\
\text { of the decline from MCI to AD; } \\
\text { isoprostane levels showed } \\
\text { longitudinal progression effects }\end{array}$ \\
\hline Lambert, $2009^{122}$ & Genomics & $\mathrm{AD}$ & $\begin{array}{l}\text { DNA } \\
\text { samples }\end{array}$ & $\begin{array}{l}\text { Markers with suggestive evidence of } \\
\text { association with AD, apart from } \\
\text { APOE, were examined; two loci } \\
\text { gave replicated evidence: one within } \\
\text { CLU (or else APOJ) on chromosome } \\
8 \text { and the other within CR1 on } \\
\text { chromosome 1; CLU and CR } 1 \text { are } \\
\text { involved in the clearance of A } \beta\end{array}$ \\
\hline Lopez, $2009^{123}$ & Proteomics & $\mathrm{AD}$ & $\begin{array}{c}\text { Blood } \\
\text { Plasma }\end{array}$ & $\begin{array}{l}\text { Plasma levels of } A \beta_{40} \text { and } A \beta_{42} \text { were } \\
\text { not associated with incident } A D \text { after } \\
\text { adjustment for age and vascular risk } \\
\text { factors; } A \beta \text { not useful as a biomarker }\end{array}$ \\
\hline Roher, $2009^{124}$ & Proteomics & $\mathrm{AD}$ & $\begin{array}{l}\text { Blood } \\
\text { Plasma, } \\
\text { Platelets \& } \\
\text { Peripheral } \\
\text { Tissues }\end{array}$ & $\begin{array}{c}\text { Plasma } \mathrm{A} \beta \text { fluctuated over time and } \\
\text { among individuals, failing as a } \\
\text { biomarker; substantially higher } \mathrm{A} \beta \\
\text { was found in liver tissue from } \mathrm{AD} \text {; } \\
\text { brain \& skeletal muscle has elevated } \\
\mathrm{A} \beta\end{array}$ \\
\hline
\end{tabular}




\begin{tabular}{|c|c|c|c|c|}
\hline Bian, $2008^{125}$ & Proteomics & AD, FTLD & CSF & $\begin{array}{l}\text { T-tau and T-tau:A } \beta_{42} \text { levels were } \\
\text { significantly lower in FTLD than in } \\
\text { AD; T-tau:A } \beta 42 \text { ratio was a sensitive } \\
\text { biomarker distinguishing FTLD from } \\
\text { AD with } 79 \% \text { sens and } 97 \% \text { specif }\end{array}$ \\
\hline Blasko, $2008^{126}$ & Proteomics & $\mathrm{AD}, \mathrm{MCI}$ & $\begin{array}{l}\text { Blood } \\
\text { Plasma }\end{array}$ & $\begin{array}{c}\text { Plasma levels of } \mathrm{A} \beta_{42} \text { alone is not a } \\
\text { suitable biomarker for predicting } \\
\mathrm{AD} ; \mathrm{A} \beta_{42} \text { increase seems to be an } \\
\text { initial event in } \mathrm{AD} \text { and changes in } \\
\text { the levels may reflect a transition } \\
\text { from HC/MCI to AD. HC to MCI } \\
\text { converters were found with } \sim 60 \% \\
\text { sens/specif, while HC to AD } \\
\text { converters with } ~ 50 \% \text { sens and } 63 \% \\
\text { specif }\end{array}$ \\
\hline Schupf, $2008^{127}$ & Proteomics & $\mathrm{AD}$ & $\begin{array}{l}\text { Blood } \\
\text { Plasma }\end{array}$ & $\begin{array}{l}\text { Higher } \mathrm{A} \beta 42 \text { levels at the onset of this } \\
4.6 \mathrm{yr} \text { follow-up study, were } \\
\text { associated with a threefold increased } \\
\text { risk of } \mathrm{AD} \text {; conversion to } \mathrm{AD} \text { was } \\
\text { accompanied by a decline in } \mathrm{A} \beta_{42} \\
\text { and } \mathrm{A} \beta_{42} \mathrm{~A} \beta_{40} \text { ratio which may } \\
\text { indicate compartmentalization of } \mathrm{A} \beta \\
\text { in the brain }\end{array}$ \\
\hline Sundelof, $2008^{94}$ & Proteomic & $\begin{array}{l}\text { AD, VaD, } \\
\text { FTD, PDD }\end{array}$ & $\begin{array}{l}\text { Blood } \\
\text { Plasma }\end{array}$ & $\begin{array}{c}\text { Low } \mathrm{A} \beta_{40} \text { levels predicted incident } \\
\text { AD in elderly men ( } 77 \mathrm{yrs}) ; \mathrm{A} \beta_{42} \text { was } \\
\text { not significantly associated with } \mathrm{AD} ; \\
\text { high ratio of } \mathrm{A} \beta_{42}: \mathrm{A} \beta_{40} \text { was } \\
\text { associated with } \mathrm{VaD} \text { risk }\end{array}$ \\
\hline Abdullah, $2007^{93}$ & Proteomics & $\mathrm{AD}$ & $\begin{array}{l}\text { Blood Serum } \\
\text { \& Plasma }\end{array}$ & $\begin{array}{c}\text { AD patients had significantly higher } \\
\mathrm{A} \beta_{40} \text { but no difference in } \mathrm{A} \beta_{42} \text { levels; } \\
\text { serum } \mathrm{A} \beta_{42} \mathrm{~A} \beta_{40} \text { ratio was lower in } \\
\mathrm{AD}\end{array}$ \\
\hline Ewers, $2007^{128}$ & Proteomics & $\mathrm{AD}, \mathrm{MCI}$ & CSF & $\begin{array}{l}\text { Levels of } \mathrm{A} \beta 42 \text { are decreased in } \mathrm{AD} \\
\text { and MCI, while levels of T-tau and } \\
\text { P-tau are increased; P-tau levels were } \\
\text { a significant predictor of conversion } \\
\text { from MCI to AD, independent of } \\
\text { age, gender, MMSE and APOE } \\
\text { genotype }\end{array}$ \\
\hline Graff-Radford, $2007^{129}$ & Proteomics & $\mathrm{AD}, \mathrm{MCI}$ & $\begin{array}{l}\text { Blood } \\
\text { Plasma }\end{array}$ & $\begin{array}{c}\mathrm{A} \beta_{42}: \mathrm{A} \beta_{40} \text { ratio may be a useful } \\
\text { premorbid biomarker for cognitive } \\
\text { normal individuals who are at risk of } \\
\text { MCI or } \mathrm{AD} \text {; subject with lower } \\
\mathrm{A} \beta_{42}: \mathrm{A} \beta_{40} \text { levels showed } \\
\text { significantly higher risk for MCI or } \\
\mathrm{AD} \text { and had greater cognitive decline }\end{array}$ \\
\hline Hansson, $2006^{130}$ & Proteomics & $\mathrm{AD}, \mathrm{MCI}$ & CSF & $\begin{array}{l}\text { CSF concentrations of T-tau, P-tau } 181 \\
\text { and A } \beta_{42} \text { were strongly associated } \\
\text { with future development of AD in } \\
\text { MCI patients; combination of T-tau }\end{array}$ \\
\hline
\end{tabular}




\begin{tabular}{|c|c|c|c|c|}
\hline & & & & $\begin{array}{c}\text { and } A \beta 42 \text { yielded } 95 \% \text { sens and } 83 \% \\
\text { specif for detection of incipient AD } \\
\text { in MCI; combination of T-tau and } \\
\text { A } \beta_{42} / \mathrm{P}-\text { tau }_{181} \text { yielded } 95 \% \text { sens and } \\
87 \% \text { specif }\end{array}$ \\
\hline Pesaresi, $2006^{131}$ & Proteomics & $\mathrm{AD}, \mathrm{MCI}$ & $\begin{array}{l}\text { Blood } \\
\text { Plasma }\end{array}$ & $\begin{array}{l}\text { Reduction of plasma } \mathrm{A} \beta_{42} \text { as marker } \\
\text { for } \mathrm{AD} \text {, specifically a transition from } \\
\mathrm{HC} / \mathrm{MCI} \text { to } \mathrm{AD}\end{array}$ \\
\hline van Oijen, $2006^{132}$ & Proteomics & $\mathrm{AD}, \mathrm{VaD}$ & $\begin{array}{l}\text { Blood } \\
\text { Plasma }\end{array}$ & $\begin{array}{c}\text { High concentrations of } A \beta_{40} \text { along } \\
\text { with low concentrations of } A \beta_{42} \\
\text { showed increased risk of dementia; } \\
\text { increased } A \beta_{42}: A \beta_{40} \text { ratio showed } \\
\text { reduced risk of dementia; } \\
\text { associations were similar for } A D \text { and } \\
\text { VaD }\end{array}$ \\
\hline Rüetschi, $2005^{133}$ & Proteomics & FTD & CSF & $\begin{array}{c}\text { Forty-two protein peaks were } \\
\text { differentially expressed in FTD in } \\
\text { comparison to non-demented } \\
\text { controls; ten peaks were selected, } \\
\text { five of which were increased and } \\
\text { five decreased, allowing sens of } 94 \% \\
\text { and specif of } 83 \% \\
\end{array}$ \\
\hline Sobow, $2005^{134}$ & Proteomics & $\mathrm{AD}, \mathrm{MCI}$ & $\begin{array}{l}\text { Blood } \\
\text { Plasma }\end{array}$ & $\begin{array}{l}\text { Plasma levels of } A \beta 42 \text { were higher in } \\
\text { MCI in comparison to } \mathrm{HC} \text { and } \mathrm{AD} \text {; } \\
\mathrm{A} \beta 40 \text { did not differ between the } \\
\text { groups; } \mathrm{A} \beta \text { would not allow an } \\
\text { accurate differential diagnosis of } \mathrm{AD} \\
\text { but might be useful for MCI patients } \\
(\sim 95 \% \text { sens and } \sim 75 \% \text { specif })\end{array}$ \\
\hline Assini, $2004^{135}$ & Proteomics & MCI & $\begin{array}{l}\text { Blood } \\
\text { Plasma }\end{array}$ & $\begin{array}{l}\text { Levels of } \mathrm{A} \beta_{42} \text { were slightly higher } \\
\text { in MCI than in HC but did not reach } \\
\text { significance; when grouped for sex, } \\
\text { women with MCI had increased } \\
\mathrm{A} \beta_{42} \text {; no significant sex-related were } \\
\text { found for } \mathrm{A} \beta_{40} \\
\end{array}$ \\
\hline Hampel, $2004^{136}$ & Proteomics & $\begin{array}{l}\text { AD, MCI, } \\
\text { VaD, FTD, } \\
\text { DLB }\end{array}$ & $\mathrm{CSF}$ & $\begin{array}{l}\text { P-tau } 181 \text { differentiated AD and DLB, } \\
\text { whereas P-tau } 231 \text { differentiated AD } \\
\text { and FTD; P-tau } 396 / 404 \text { was a } \\
\text { promising biomarker to differentiate } \\
\text { AD and VaD; high P-tau } 231 \text { levels } \\
\text { may indicate progressive cognitive } \\
\text { decline in MCI subjects }\end{array}$ \\
\hline Fukumoto, $2003^{137}$ & Proteomics & $\mathrm{AD}$ & $\begin{array}{l}\text { Blood } \\
\text { Plasma }\end{array}$ & $\begin{array}{c}\text { Plasma } \mathrm{A} \beta \text { levels increased } \\
\text { significantly with age but were } \\
\text { correlated to age rather than } \\
\text { diagnosis, medication or } A P O E \\
\text { genotype, thus } \mathrm{A} \beta \text { is not sensitive or } \\
\text { specific biomarker of AD or MCI }\end{array}$ \\
\hline Zetterberg, $2003^{138}$ & Proteomics & $\mathrm{AD}, \mathrm{MCI}$ & $\mathrm{CSF}$ & $\begin{array}{c}\text { Combination of three CSF } \\
\left.\text { biomarkers (T-tau, P-tau, } A \beta_{42}\right) \text { can }\end{array}$ \\
\hline
\end{tabular}




\begin{tabular}{|c|c|c|c|c|}
\hline & & & & $\begin{array}{l}\text { detect early AD among patients with } \\
\text { MCI with } 68 \% \text { sens and } 97 \% \text { specif }\end{array}$ \\
\hline Mehta, $2000^{139}$ & Proteomics & $\mathrm{AD}$ & $\begin{array}{c}\text { CSF \& } \\
\text { Blood } \\
\text { Plasma }\end{array}$ & $\begin{array}{c}\text { Plasma } A \beta_{40} \text { elevated in AD but not } \\
\text { useful to support the clinical } \\
\text { diagnosis due to considerable } \\
\text { overlap; plasma } A \beta_{42} \text { similar between } \\
\text { AD and HC; CSF A } \beta_{40} \text { similar } \\
\text { between AD and HC; CSF A } \beta 42 \\
\text { lower in AD }\end{array}$ \\
\hline Vanderstichele, $2000^{140}$ & Proteomics & $\mathrm{AD}, \mathrm{DLB}$ & $\begin{array}{l}\text { CSF, Urine, } \\
\text { Blood Serum } \\
\text { \& Plasma }\end{array}$ & $\begin{array}{l}\mathrm{A} \beta_{42} \text { in serum and urine were below } \\
\text { detection limit; in plasma no } \mathrm{A} \beta_{42} \\
\text { differences were seen between HC } \\
\text { and patients; CSF } \mathrm{A} \beta_{42} \text { was lower in } \\
\mathrm{AD} \text { and DLB suggesting it as a } \\
\text { useful biomarker }\end{array}$ \\
\hline Andreasen, $1999^{141}$ & Proteomics & $\mathrm{AD}$ & $\mathrm{CSF}$ & $\begin{array}{c}\text { Decreased } \mathrm{A} \beta_{42} \text { levels were could } \\
\text { serve as diagnostic biomarker in } \mathrm{AD} \\
\text { ( } 92 \% \text { sens); no significant } \\
\text { correlations between CSF } \mathrm{A} \beta_{42} \text { level } \\
\text { and duration or severity }\end{array}$ \\
\hline Kanai, $1998^{142}$ & Proteomics & $\mathrm{AD}$ & CSF & $\begin{array}{c}\text { Significant elevation of tau levels } \\
\text { and } A \beta_{40} A \beta_{42} \text { ratio, as well as } \\
\text { decrease of } A \beta_{42} \text { levels, were } \\
\text { observed in AD patients; the assays } \\
\text { provided } ~ 70 \% \text { sens. and } 83 \% \\
\text { specif. }\end{array}$ \\
\hline Motter, $1995^{143}$ & Proteomics & $\mathrm{AD}$ & CSF & $\begin{array}{l}\mathrm{A} \beta_{42} \text { levels were found significantly } \\
\text { lower in } \mathrm{AD} \text { while total } \mathrm{A} \beta \text { levels } \\
\text { were not, suggesting that diminished } \\
\mathrm{A} \beta 42 \text { clearance may account for its } \\
\text { reduction in CSF; tau levels were } \\
\text { increased in AD }\end{array}$ \\
\hline
\end{tabular}

Spectroscopic Tests

\begin{tabular}{c|c|c|c|c}
\hline Huang, $2017^{144}$ & $\begin{array}{c}\text { Raman } \\
\text { spectroscopy }\end{array}$ & AD & $\begin{array}{c}\text { Brain Tissue, } \\
\text { Blood Serum } \\
\text { \& Plasma } \\
\text { Michael, 2017 } 145\end{array}$ & $\begin{array}{c}\text { Biomarkers of AD, such as A } \beta \text { and } \\
\text { tauteins or the neurotransmitters } \\
\text { involved in AD }(e . g ., \text { glutamate and } \\
\gamma \text {-aminobutyric acid), have been } \\
\text { identified to distinguish patients } \\
\text { from HC individuals }\end{array}$ \\
\hline Spectroscopy & AD & Brain Tissue & $\begin{array}{c}\text { Tissue imaging identified plaques } \\
\text { and tangles in unstained, label-free } \\
\text { brain tissue; two times more proteins } \\
\text { and five times more } \beta \text {-sheets were } \\
\text { found inside the plaque- and tangle- } \\
\text { like features, as compared to the } \\
\text { surrounding tissue }\end{array}$ \\
\hline Paraskevaidi, 2017 99 & $\begin{array}{c}\text { ATR-FTIR } \\
\text { Spectroscopy }\end{array}$ & $\begin{array}{c}\text { AD, DLB, } \\
\text { FTD }\end{array}$ & $\begin{array}{c}\text { Blood } \\
\text { Plasma }\end{array}$ & $\begin{array}{c}\text { AD patients were detected with } 86 \% \\
\text { sens and specif when individuals had }\end{array}$ \\
\hline
\end{tabular}




\begin{tabular}{|c|c|c|c|c|}
\hline & & & & $\begin{array}{l}\text { one or two alleles of APOE } \varepsilon 4 \text {, while } \\
\text { in individuals with no } \varepsilon 4 \text { alleles } \\
\text { diagnostic accuracy was lower at } \\
72 \% \text { sens and } 77 \text { specif; early AD } \\
\text { cases were distinguished with } 80 \% \\
\text { sens and } 74 \% \text { specif; differences } \\
\text { coming with AD duration were also } \\
\text { noted; AD was also distinguished } \\
\text { from DLB with } 90 \% \text { sens and specif; } \\
\text { FTD was also segregated from HC }\end{array}$ \\
\hline Paraskevaidi, 2017 & $\begin{array}{c}\text { Raman } \\
\text { Spectroscopy }\end{array}$ & $\mathrm{AD}, \mathrm{DLB}$ & $\begin{array}{l}\text { Blood } \\
\text { Plasma }\end{array}$ & $\begin{array}{l}\text { Early-stage AD was detected with } \\
84 \% \text { sens and } 86 \% \text { specif; late-stage } \\
\text { AD was detected with } 84 \% \text { sens and } \\
77 \% \text { specific; DLB was detected } \\
\text { with } 83 \% \text { sens and } 87 \% \text { specif; late- } \\
\text { stage AD was distinguished from } \\
\text { DLB with } 90 \% \text { sens and } 93 \% \text { specif; } \\
\text { wavenumbers assigned to specific } \\
\text { biomolecules were also suggested as } \\
\text { a panel of biomarkers }\end{array}$ \\
\hline Mordechai, $2017^{146}$ & $\begin{array}{c}\text { FTIR } \\
\text { Spectroscopy }\end{array}$ & $\mathrm{AD}$ & $\begin{array}{c}\text { Blood } \\
\text { Plasma \& } \\
\text { White Blood } \\
\text { Cells }\end{array}$ & $\begin{array}{l}\text { Mild, moderate and severe cases of } \\
\text { AD were distinguished from HC } \\
\text { individuals with } 85 \% \text { accuracy when } \\
\text { using white blood cells and } \sim 77 \% \\
\text { when using blood plasma }\end{array}$ \\
\hline Nabers, $2016^{98}$ & $\begin{array}{c}\text { FTIR } \\
\text { Spectroscopy }\end{array}$ & $\mathrm{AD}$ & $\begin{array}{l}\text { CSF \& } \\
\text { Blood } \\
\text { Plasma }\end{array}$ & $\begin{array}{l}\text { Employing an immune-IR-sensor, } \\
\text { there was a discrimination between } \\
\text { AD and HC with a } 90 \% \text { accuracy in } \\
\text { CSF and } 84 \% \text { in blood plasma; a } \\
\text { significant downshift, indicative of } \\
\text { the overall } \beta \text {-sheet structure, was } \\
\text { noted in the AD patients }\end{array}$ \\
\hline Kiskis, $2015^{147}$ & CARS & $\mathrm{AD}$ & Brain Tissue & $\begin{array}{l}\text { Enhanced Raman imaging of tissue } \\
\text { sections from the prefrontal cortex } \\
\text { showed evidence of lipid deposits } \\
\text { co-localizing with } A \beta \text { plaques }\end{array}$ \\
\hline Demeritte, $2015^{148}$ & SERS & $\mathrm{AD}$ & Whole Blood & $\begin{array}{l}\text { Antibody-coated nanoparticles were } \\
\text { used to enhance the Raman signal; } \\
\mathrm{A} \beta \text { and tau proteins were both } \\
\text { detected in concentrations as low as } \\
100 \mathrm{fg} / \mathrm{mL} \text { level; the spectroscopic } \\
\text { technique showed advantages over } \\
\text { ELISA detecting } \mathrm{A} \beta(0.312 \mathrm{ng} / \mathrm{mL}) \\
\text { and tau }(0.15 \mathrm{ng} / \mathrm{mL})\end{array}$ \\
\hline Ryzhikova, $2015^{149}$ & $\begin{array}{c}\text { Raman } \\
\text { Spectroscopy }\end{array}$ & $\begin{array}{l}\text { AD, DLB, } \\
\text { FTD }\end{array}$ & Blood Serum & $\begin{array}{l}\text { Patients with AD were differentiated } \\
\text { from HC and other dementias with } \\
\sim 95 \% \text { sens and specif }\end{array}$ \\
\hline Carmona, $2015^{97}$ & $\begin{array}{l}\text { Raman and IR } \\
\text { Spectroscopy }\end{array}$ & $\mathrm{AD}$ & $\begin{array}{l}\text { Blood } \\
\text { Plasma }\end{array}$ & $\begin{array}{l}\text { Patients with AD and age-matched } \\
\text { healthy controls were distinguished } \\
\text { with a diagnostic accuracy of } \sim 94 \%\end{array}$ \\
\hline
\end{tabular}




\begin{tabular}{|c|c|c|c|c|}
\hline Magierski, $2014{ }^{150}$ & $\begin{array}{c}\text { Magnetic } \\
\text { Resonance } \\
\text { Spectroscopy }\end{array}$ & $\mathrm{AD}, \mathrm{DLB}$ & $\begin{array}{l}\text { In vivo Brain } \\
\text { Tissue } \\
\text { Imaging }\end{array}$ & $\begin{array}{c}\text { Proton magnetic resonance } \\
\text { spectroscopy has been demonstrated } \\
\text { as a noninvasive method to assess } \\
\text { the biochemistry of brain tissue in } \\
\text { vivo }\end{array}$ \\
\hline Carmona, $2013^{151}$ & $\begin{array}{l}\text { Raman and IR } \\
\text { Spectroscopy }\end{array}$ & $\mathrm{AD}$ & $\begin{array}{l}\text { Blood } \\
\text { Plasma }\end{array}$ & $\begin{array}{l}\text { Spectral biomarkers were identified } \\
\text { in the Raman and IR region and were } \\
\text { indicative of protein secondary } \\
\text { structure, protein } \alpha \text {-helices, protein } \\
\text { tertiary structure and oxidative } \\
\text { stress; the diagnostic accuracy } \\
\text { achieved } 89 \% \text { sens and } 92 \% \text { specif }\end{array}$ \\
\hline Luo, $2013^{152}$ & $\begin{array}{c}\text { Raman } \\
\text { Spectroscopy }\end{array}$ & $\mathrm{AD}$ & Platelets & $\begin{array}{l}\text { Early and differential (from PD) } \\
\text { diagnosis of AD was demonstrated; } \\
80 \% \text { sens. for } 12 \text {-month AD, } 75 \% \\
\text { sens. for 4-month AD and } 100 \% \\
\text { specif. were achieved }\end{array}$ \\
\hline Chen, $2011^{153}$ & $\begin{array}{c}\text { Raman } \\
\text { Spectroscopy }\end{array}$ & $\mathrm{AD}, \mathrm{VaD}$ & Platelets & $\begin{array}{l}\text { Early and differential diagnosis of } \\
\text { AD from VaD; two peaks }\left(740 \mathrm{~cm}^{-1} \text { : }\right. \\
\text { protein side chain vibration and } 1654 \\
\mathrm{~cm}^{-1} \text { : Amide I of the protein } \alpha \text {-helix } \\
\left.\text { structure }{ }^{154}\right) \text { were mostly } \\
\text { responsible for the segregation } \\
\text { between HC and AD }\end{array}$ \\
\hline Leskovjan, $2010^{96}$ & $\begin{array}{c}\text { FTIR } \\
\text { Spectroscopy }\end{array}$ & $\mathrm{AD}$ & Brain Tissue & $\begin{array}{l}\text { FTIR imaging was used to visualize } \\
\text { the unsaturated lipid content in } \\
\text { specific regions of the hippocampus } \\
\text { in an AD mouse model as a function } \\
\text { of plaque formation; the unsaturated } \\
\text { lipid content was reduced in the } \\
\text { hippocampal white matter during A } \beta \\
\text { pathogenesis } \\
\text { pathe }\end{array}$ \\
\hline Burns, $2009^{155}$ & $\begin{array}{c}\text { NIR } \\
\text { Spectroscopy }\end{array}$ & $\mathrm{AD}$ & $\begin{array}{l}\text { Blood } \\
\text { Plasma }\end{array}$ & $\begin{array}{l}\text { Five spectral bands corresponding to } \\
\text { heme, R-CH, R-OH, } \mathrm{H}_{2} \mathrm{O} \text { and } \mathrm{R}-\mathrm{NH} \\
\text { were used to distinguish between } \mathrm{AD} \\
\text { and } \mathrm{HC} \text { with } 80 \% \text { sens and } 77 \% \\
\text { specif; spectra were not influenced } \\
\text { by age, gender, exposure to } \\
\text { cholinesterase inhibitors or sample } \\
\text { storage time }\end{array}$ \\
\hline Chen, $2009^{156}$ & $\begin{array}{c}\text { Raman } \\
\text { Spectroscopy }\end{array}$ & $\mathrm{AD}$ & $\begin{array}{l}\text { Brain } \\
\text { Hippocampu } \\
\text { s Tissue }\end{array}$ & $\begin{array}{l}\text { In situ Raman analysis distinguished } \\
\text { AD from normal tissue; biochemical } \\
\text { changes that were observed included } \\
\text { the increase of } A \beta \text { protein, } \\
\text { cholesterols and } \\
\text { hyperphosphorylated tau }\end{array}$ \\
\hline Peuchant, $2008{ }^{157}$ & $\begin{array}{c}\text { FTIR } \\
\text { Spectroscopy }\end{array}$ & $\mathrm{AD}$ & $\begin{array}{l}\text { Blood } \\
\text { Plasma }\end{array}$ & $\begin{array}{l}\text { A clear separation was achieved } \\
\text { between AD and HC by using a } \\
\text { restricted spectral range; changes } \\
\text { were related to modified lipid and }\end{array}$ \\
\hline
\end{tabular}




\begin{tabular}{|c|c|c|c|c|}
\hline & & & & $\begin{array}{l}\text { nucleic acid structures involved in } \\
\text { oxidative stress processes of AD; the } \\
\text { diagnostic accuracy was } \sim 98 \%\end{array}$ \\
\hline Kantarci, $2004^{158}$ & $\begin{array}{c}\text { Magnetic } \\
\text { Resonance } \\
\text { Spectroscopy }\end{array}$ & $\begin{array}{c}\text { AD, VaD, } \\
\text { DLB, FTLD }\end{array}$ & $\begin{array}{l}\text { In vivo Brain } \\
\text { Tissue } \\
\text { Imaging }\end{array}$ & $\begin{array}{l}\text { Metabolite ratio changes were } \\
\text { evaluated and shown as useful } \\
\text { imaging markers in common } \\
\text { dementias; N- } \\
\text { Acetylaspartate/creatine levels were } \\
\text { decreased in dementias that undergo } \\
\text { neuron loss such as AD, FTLD and } \\
\text { VaD; myoinositol/creatine were } \\
\text { elevated in dementias pathologically } \\
\text { characterized by gliosis such as AD } \\
\text { and FTLD; choline/creatine was } \\
\text { increased in dementias with a } \\
\text { profound cholinergic deficit such as } \\
\text { AD and DLB }\end{array}$ \\
\hline Choo, $1996^{95}$ & $\begin{array}{c}\text { FTIR } \\
\text { Spectroscopy }\end{array}$ & $\mathrm{AD}$ & Brain tissue & $\begin{array}{l}\text { The structure of } A \beta \text { protein within a } \\
\text { slice of human AD brain tissue was } \\
\text { reported for the first time; protein in } \\
\text { grey matter existed predominantly in } \\
\text { an } \alpha \text {-helical and/or unordered } \\
\text { conformation, whereas within } \\
\text { amyloid deposits a beta-sheet } \\
\text { structure predominated }\end{array}$ \\
\hline
\end{tabular}

979 Abbreviations: A $\beta$ : amyloid beta; AD: Alzheimer's disease; APOE: apolipoprotein; APOJ: 980 apolipoprotein J; ATR: attenuated total reflection; CSF: cerebrospinal fluid; CLU: clusterin; 981 CR1: complement component (3b/4b) receptor 1; CT: computed tomography; CARS: Coherent 982 anti-Stokes Raman Scattering; DAT: dopamine transporter; ELISA: enzyme linked 983 immunosorbent assay; fg: femtogram; ${ }^{18} \mathrm{FDG}:{ }^{18}$ fluorodeoxyglucose; FTIR: Fourier transform 984 infrared spectroscopy; FTD: frontotemporal dementia; FTLD: frontotemporal lobe 985 degeneration; YKL-40: glial activation; HC: healthy controls; HFABP: heart fatty acid binding 986 protein; hrs: hours; MRI: magnetic resonance imaging; MTL: medial temporal lobe; MIBG: 987 metaiodobenzylguanidine; MCI: mild cognitive impairment; MMSE: mini mental state 988 examination; NIR: near-infrared; NFL: neurofilament light chain; NSE: neuron-specific 989 enolase; PD: Parkinson's disease; PDD: Parkinson's disease dementia; P-tau: phosphorylated 990 tau; PET: positron emission tomography; sens: sensitivity; SPECT: single-photon emission 991 computed tomography; specif: specificity; SERS: surface enhanced Raman spectroscopy; T992 tau: total tau; VaD: vascular dementia; VLP-1: vinisin-like protein 1; yrs: years; 